\title{
Research on Forward Osmosis Membrane Technology Still Needs Improvement in Water Recovery and Wastewater Treatment
}

\author{
Li Li ${ }^{1,2}$, Wenxin Shi ${ }^{1,3}$ and Shuili Yu ${ }^{1, *}$ \\ 1 State Key Laboratory of Urban Water Resource and Environment, School of Environment, \\ Harbin Institute of Technology, Harbin 150090, China; hitolina@hit.edu.cn (L.L.); swx@hit.edu.cn (W.S.) \\ 2 College of Environmental Science \& Engineering, Qilu University of Technology, Jinan 250353, China \\ 3 School of Civil Engineering, Chongqing University, Chongqing 400044, China \\ * Correspondence: yushuilihit@126.com
}

Received: 20 November 2019; Accepted: 26 December 2019; Published: 29 December 2019

\begin{abstract}
Forward osmosis (FO) has become an evolving membrane separation technology to recover water due to its strong retention capacity, sustainable membrane fouling, etc. Although a good deal of research has been extensively investigated in the past decades, major challenges still remain as follows: (1) the novel FO membrane material properties, which significantly influence the fouling of the FO membranes, the intolerance reverse solute flux (RSF), the high concentration polarization $(\mathrm{CP})$, and the low permeate flux; (2) novel draw solution preparation and utilization; (3) salinity build-up in the FO system; (4) the successful implementation of the FO process. This work critically reviews the last five years' literature in development of the novel FO membrane material, structure in modification, and preparation, including comparison and analysis on the traditional and novel draw solutes coupled with their effects on FO performance; application in wastewater treatment, especially hybrid system and integrated FO system; fouling mechanism; and cleaning strategy as discussed in the literature. The current barriers of the research results in each hotspot and the areas that can be improved are also analyzed in detail. The research hotspots in the research and development of the novel membrane materials in various countries and regions have been compared in recent years, and the work of variation in pop research hotspots in the past 10 years has been analyzed and the ideas that fill the blank gaps also have been proposed.
\end{abstract}

Keywords: forward osmosis; reverse solute flux; draw solutes; fouling mechanism

\section{Introduction}

With the growth of population and economy, the water crisis posed by the increasing demand for water resources and aggravating water pollution has become one of the most serious problems in the 21st century. In the last decade, a growing number of research and technological efforts were conducted for wastewater treatment and reuse. Especially, the pressure-driven membrane technologies such as microfiltration (MF), ultrafiltration (UF), nanofiltration (NF), and reverse osmosis (RO) received extensive attention and application in wastewater treatment and seawater desalination. However, the aforementioned technologies are mainly faced with three major challenges: high energy consumption due to high pressure, strict pretreatment process, and severe membrane fouling [1]. Therefore, increasing awareness of potential cost savings from energy consumption reduction has prompted significant research efforts to develop novel materials and technologies for wastewater treatment.

In recent years, forward osmosis (FO), as an osmotic pressure-driven membrane process, demonstrated great application prospects to solve the global challenges of water and energy [2]. 
FO is a membrane-based separation process driven by the osmotic pressure difference between the two sides of the membrane. The water molecules spontaneously diffuse from the lower osmotic pressure side to the higher side through the semi-permeable membrane without external pressure. The low osmotic pressure side is referred to as the 'feed solution' (FS), which is gradually concentrated. The high osmotic pressure side is referred to as the draw solution (DS), which is continuously diluted with the infiltrated water. Finally, clean water is obtained by separating the solute. The process requires no additional pressure, as opposed to the RO process.

Compared with other membrane technologies, FO has prominence advantages such as high energy-efficiency, low fouling propensity, high salt rejection, and low brine discharge. First of all, as a spontaneous infiltration process that does not require additional driven pressure, FO has the potential for low energy consumption [3]. With the appropriate DS and recycling method, this point will become the most attractive advantage of FO. However, Shaffer et al. [4] proposed that FO hybrid systems are energy-efficient only when applied to the desalination of high-salinity feed waters using thermolytic DS. Secondly, the pore size of FO membrane is only about $0.3-0.5 \mathrm{~nm}$ which can guarantee a high rejection rate of solute and application of desalination [5], heavy metal removal [6], micro-pollutant (cytostatic drugs, endocrine disruptors, personal care chemicals, etc.) removal [7]. Furthermore, pretreatment is not required for the treatment of complex wastewater. Another significant advantage of FO is the low pollution propensity. The membrane fouling is dominated by reversible fouling which can be restored by simple hydraulic cleaning [8]. This is a significant advantage when FO is applied to treat brine with high concentration. When seawater is used as a DS, diluted seawater can be directly discharged into the sea without being concentrated and recycled. After being concentrated, the FS can be further used to generate energy through anaerobic digestion [9]. Another form of osmosis process, pressure retarded osmosis (PRO), can convert the osmotic pressure differences between seawater and freshwater into electrical energy [10].

Despite the inherent advantages and broad application prospects, large-scale commercialization of the FO process has not been adequately possible due to some obstacles such as regeneration and separation of draw solutes, concentration polarization (CP) on the feed side, reverse solute diffusion (RSD), and membrane fouling [11]. Osmosis pressure, which is provided by DS, is the driving force for mass transport. The type and concentration of DS are important factors affecting the performance of FO process [12,13]. Besides, to separate the draw solutes, energy-intensive methods-such as $\mathrm{NF}, \mathrm{RO}$, and membrane distillation (MD) — are often integrated with FO. The investment and energy consumption of the integrated system has become a new problem [3]. Furthermore, CP and RSD are two significant factors impeding FO performance [14]. The water permeation of the membranes will be adversely affected due to the reduced osmotic pressure gradient across the active layer resulting from an increase osmotic pressure on the membrane active layer surface $[15,16]$. Also due to the concentration gradient, reverse diffusion of draw solute to the FS seems to be unavoidable [17]. The RSD can not only reduce the concentration gradient and water flux but also increase CP and membrane fouling. Additionally, to reduce membrane fouling, researchers have made a lot of efforts in terms of membrane materials [18], membrane structures, and process combinations [19].

In the paper, the following contents are reviewed: (i) the latest improvement and the defaults in modification and preparation of FO membrane, the possible suggestions in the FO membrane preparation perfection; (ii) summary of the traditional draw solute specialties, classifications of the novel draw solutes discussed in the literatures; (iii) application of FO in wastewater treatment, especially salinity build-up in the FO system, the success implement of the FO process; (iv) recent developments on membrane fouling and cleaning strategy.

\section{Forward Osmosis Membrane}

The membrane plays a substantial role in FO performance. In the early studies, FO researchers mainly used commercially available RO or NF membranes to study the FO process. However, $\mathrm{RO}$ membranes have a thick hydrophobic support layer resulting in severe $\mathrm{CP}$ and poor FO 
performance [20]. Until the 1990s, Hydration Technology Innovation (HTI) started developing the FO membrane and developed a widely used commercial triacetate cellulose (CTA) membrane with an asymmetric structure. The active layer is made of triacetate cellulose embedded with a polyester mesh-type support layer. However, the salt rejection of the CTA membrane is not high and the $\mathrm{pH}$ tolerance range is narrow [21]. In 2010, the first commercial thin-film composite (TFC) membranes were developed by Oasys Water Inc. Compared with CTA membranes, TFC membranes have higher initial water flux, higher perm-selectivity, a wider range of $\mathrm{pH}$, and better chemical stability [22]. However, TFC membranes were also reported to have a higher fouling propensity than CTA membranes due to high initial water flux, high surface roughness, and strong hydrogen bonding capacity [23-25].

The characteristics of the FO membrane are crucial in the performance of the FO process. High water flux and solutes rejection are essential for the most ideal FO membrane. The following characteristics are necessary for ideal TFC-FO membrane which is as shown in Figure 1: (1) The active layer should be dense and ultra-thin to have a high rejection rate for solute; (2) The support layer should be thin enough and high mechanical strength; (3) The membrane should have a high hydrophilicity to increase the water flux, anti-fouling property and $\mathrm{CP}$ alleviation; (4) The membrane should have a wide $\mathrm{pH}$ and temperature tolerance and oxidation resistance range.

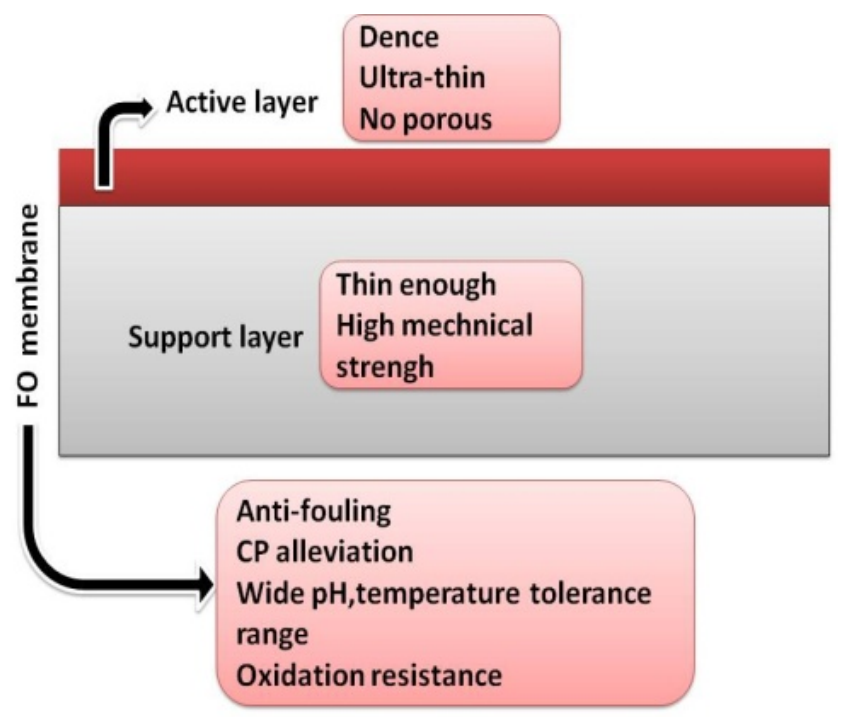

Figure 1. The ideal TFC-FO membrane model.

In recent years, significant advancements have been made by researchers on novel membrane materials to increase water flux and solute rejection, reduce internal concentration polarization (ICP) and RSD, and enhance the tolerance to water quality.

\subsection{Membrane Structure and Materials}

The ideal TFC-FO membrane should have a high-performance dense active layer and no porous support layer [21]. In order to provide satisfying mechanical strength since the support layer is essential, the most existing TFC membranes are prepared into a thicker form with a thick porous support layer. However, such asymmetric structure always causes severe ICP within the thick support layer, leading to an obvious loss of osmosis pressure and water flux [26]. As shown in references, differ from external concentration polarization (ECP), ICP within the support layer cannot be eliminated by enhancing the cross-flow velocity and turbulence along the membrane surface [27]. Hence, ICP has also been a rigorous obstacle to the process of FO. To resolve this dilemma, lots of research efforts have been made.

Researchers have made a lot of improvements and attempts around the active layer and support layer materials in recent five years. Research on the support layer is more focused as it is the place where ICP happed. Nanomaterials (such as nanofibers and nanocellulose) have proven to be effective 
materials of support layer which can improve membrane structure, reduce ICP and enhance water flux [28]. Choi et al. [29] blended functionalized carbon nanotube (fCNT) into polyethersulfone (PES) support layer to enhance hydrophilicity and increased the water flux by $72 \%$ compared to that of the TFC membrane. Pan [30] developed a PA/PAN-eTFC membrane supported by hydrophilic electrospun PAN nanofiber with a scaffold-like structure. The hydrophilicity, flexibility, and mechanical strength were all remarkably improved.

To get higher membrane permeability, other materials are also applied to membrane fabrication nearly. The high water permeability and single selectivity of aquaporin (AQP) promoted researchers to develop AQP biofilms from different approaches. It is decorated in the active layer forming biomimetic membranes which has also been widely studied [31].

It is reported that the permeation flux of the biomimetic membrane containing AQP reached up to $6010 \mathrm{~L} /\left(\mathrm{h} \cdot \mathrm{m}^{2} \cdot \mathrm{MPa}\right)$ [32]. According to different membrane structures, AQP biomimetic membranes are mainly divided into two categories: biomimetic membranes supporting double membranes structure as AQP carriers and biomimetic membrane packaging AQP vesicles. The two types have the characteristics of AQP carriers with better activity and stronger mechanical strength and stability, respectively. However, the complex conditions of FS such as temperature, $\mathrm{pH}$ and the presence of chemicals may affect the performance of the aquaporin-based biomimetic membrane.

In Zhao's study [33], the addition of bovine serum albumin (BSA) in the PA active layer improved the dissolution-diffusion process of the traditional PA layer by providing the swellable sites as water channels in aqueous solutions and enhanced the rejection effect on heavy metal ions.

A hydrogel FO membrane is explored for treating wastewaters of high concentration organic pollutants. This FO membrane has an ultrathin hydrogel selective layer, which is highly hydrophilic (water contact angle as low as $18^{\circ}$ ) and smooth (surface roughness $<5 \mathrm{~nm}$ ) [34].

Except for organic matters, inorganic materials are also applied to essential FO membranes. You $S$ et al. [26,35] developed a new kind of thin-film inorganic membrane made of microporous silica xerogels immobilized onto a stainless steel mesh (SSM) substrate, reaching an average rejection efficiency of $94 \%$ for heavy metals. Water-stable metal-organic framework UiO-66 was explored to fabricate high-performance mixed-matrix membranes which exhibited a $50 \%$ increased water flux over the commercial membrane [36]. Nanocellulose was decorated silver and platinum nanoparticles as additive materials to fabricate the support layer of thin film composite (TFC) membranes for water purification applications [37]. Three times higher water flux than the commercial membrane was obtained.

A double-skinned membrane structure was designed with a porous support sandwiched between two rejection skins [38]. One active skin face to the DS to prevent RSD and another to the FS to prevent the membrane fouling. An anti-fouling double-skinned FO membrane composed with a fully porous sublayer sandwiched between a highly dense polyamide (PA) layer and a fairly loose dense bottom zwitterionic layer made up of a zwitterionic polyelectrolyte brush was used for highly contaminated emulsified oil-water treatment [39]. Much lower fouling propensity and higher water flux $\left(13.7 \pm 0.3 \mathrm{~L} / \mathrm{m}^{2}, 2 \mathrm{M} \mathrm{NaCl}\right)$ were observed compared with the single-skinned membrane.

Bao $[40,41]$ strengthened the rejection of ammonia nitrogen in the wastewater by the surface grafting of PEI. Studies had shown that the ammonia nitrogen rejection of the TFC membrane was mainly determined by the primary amino group density of the surface of the grafted membrane, Bao further enhanced the hydrophilicity and ammonia nitrogen selectivity of the forward osmotic membrane by surface grafting of PAMAM dendrimer. The terminal primary amino group on the outer side of the PAMAM molecule could effectively encapsulate the tertiary amine group into the molecule. The surface with FG-G2 primary amino group had the highest selectivity for ammonia nitrogen, and it had the best anti-membrane pollution performance in concentrated domestic sewage.

Changing the composition of the membrane material by adding substances could enhance certain characteristics of the forward osmosis membrane. Some enhanced the hydrophilicity by adding a hydrophilic substance, to increase the membrane permeability. Some enhanced the contaminant 
rejection rate by exploiting a special material as a support layer, and some grafted. These Methods make the forward osmosis membranes have special functions and have outstanding performance in special application fields, such as intercepting heavy metals, ionic radii, and ammonium ions with similar water molecule radius.

\subsection{Modifications on FO Membranes}

In order to improve membrane properties, membrane modification is proven to be feasible and effective. Generally, two kinds of modification can be chosen, physical modification and chemical modification [42].

In the physical modification, membrane composition and structure are changed by adding hydrophilic materials into either raw material or membrane surfaces without any chemical reaction [43]. Physical modification methods include blending, surface coating, and in-situ interfacial polymerization.

Many researchers have studied physical modification. For instance, Emadzadeh et al. [44] synthesized thin film nanocomposite membranes by adding modified nanoporous titanate (mNTs) nanoparticle into polyamide selective layer by in-situ interfacial polymerization. The flux decline of NM1 (the mNTs concentration of 0.01 wt \%) caused by the multi-component (organic and inorganic) foulant was recorded at $13 \%$ that was significantly lower than that of control membrane (53\%). In Salehi's study [45], zeolite nanoparticles were blended into polyethersulfone (PES) support layer and the water flux of the resulting membrane was $43 \%$ higher than the control TFC membrane $\left(1.93 \mathrm{~L} / \mathrm{m}^{2} \mathrm{~h} \mathrm{bar}\right)$ with salt rejection recorded at $94.7 \%$. Many other nanomaterials have also been used in blending methods to modify FO membranes, such as graphene oxide (GO), carbon nanotube [46], titanium dioxide [47], and silica [35]. These studies confirmed that physical modification can effectively improve hydrophilicity and porosity of membrane which leads to higher water flux without reducing rejection.

Although the aforementioned studies show that physical modification is conductive to improve FO membrane performance, the improvement is very limited and added materials are likely to leak out after the long-term operation. In addition, the RSD may get worse due to the improved porosity.

Comparatively, the chemical modification that is more effective in improving membrane performance than physical modification receives more attention.

In Liu's study [48], a progressive substrate membrane surface modification via polydopamine (PDA) deposition was conducted to improve surface hydrophilicity and anti-fouling property. After hydraulic cleaning, it demonstrated more than $93.0 \%$ of water flux recovery in the AL-DS orientation after cleaning as well as significantly surpassing the performance over unmodified double-skinned TFC-Psf-0 (81.7\%) and single-skinned TFC-Psf-S (61.7\%) under the same testing condition.

Shen et al. [49] modified the nascent TFC membranes by grafting a self-catalyzed tripodal amine-tris (2-aminoethyl) amine (TAEA) which was conductive to react with acyl chloride groups and accelerate the amidation reaction between 1,3,5-trimesoyl chloride (TMC) and TAEA.

Besides, $\mathrm{Xu}$ et al. [42] reviewed the advantages and disadvantages of the chemical modification methods, typical FO applications of chemically modified FO membranes and challenges in the current chemical modification approaches.

In the preparation of TFC film, the current literature mainly focused on the modification of the surface properties of the active layer and its possible contamination mechanism, however, the mechanism of the influence of the support layer on the surface properties of the active layer was less studied.

Singh et al. [50] did some research on the effect of pore size in the support layer on the water permeability flux and salt removal efficiency of the TFC membrane. Kim [51] analyzed the effect of the hydrophobicity of the support layer on the selectivity of the TFC membrane. Ghosh [52] studied the relationship between the support layer and the surface topography of the active layer.

Vrijen Hoek et al. [53] found that the "ridge-valley" convex structure on the surface of the polyamide active layer of TFC, which increased the roughness of the surface of the film and promoted the formation of membrane fouling. The rough surface structure increased the surface area of the 
membrane, and the contaminants were more likely to adhere. At the same time, the convex structure was suitable to shield the shearing force of the water, so that the contaminants were not easily removed by cleaning, and the probability of irreversible pollution was increased.

Ramon et al. [54] analyzed the possible influence mechanism of the support layer on the active layer pollution characteristics through computer simulation, but lacked experimental data to further analyze and verify the model.

All of the above studies demonstrated that the surface properties of the support layer of the positive osmosis membrane have a significant effect on the mass transfer and surface morphology of the active layer.

In the last six years, the number of research on the development of the FO membrane materials and the modification of the FO membranes has increased year by year as shown in Figure 2. Among them, the number of research papers in PRC. Australia was the highest during the year 2014 to 2018, it was worth noting that the number of Iran studies had gradually increased over the past six years, from 0 to 14 articles, even the number of research papers exceeded Australia in 2019, which became the second. In contrast, the number of studies in Singapore had decreased from max 8 to 2.

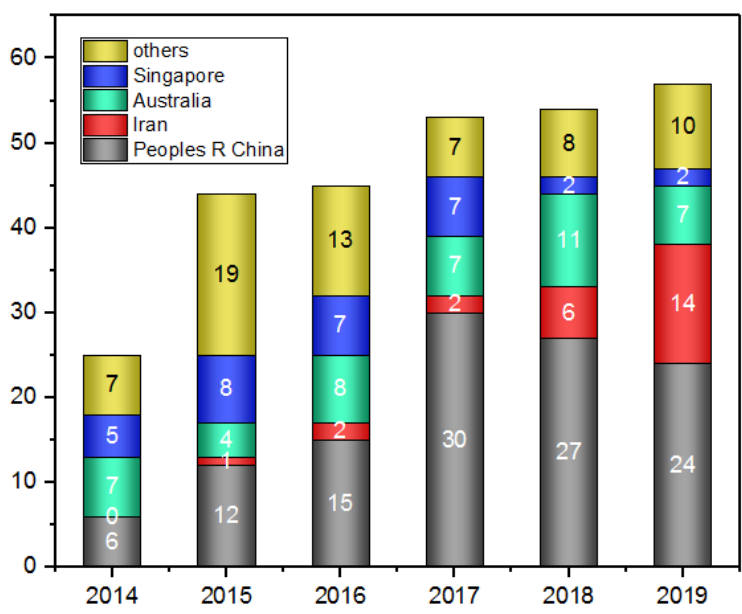

Figure 2. Number of research papers on the novel FO membrane in recent years.

Although lots of research on the preparation and modification of FO membrane materials have been carried out and making breakthroughs in a particular property or specialty, there are still critical drawbacks in the progress of membrane materials. Among the following characteristics: high membrane flux; high rejection rate for contaminants in broad category; under the variation of draw solute, the RSF is lower; the influence of CP is lower; the chemical structure of support layer is stable and the mechanical strength is satisfied; the $\mathrm{pH}$ tolerance of membrane is broad; the application temperature is wide and the influence of membrane efficiency affected by temperature is negligible; the preparation materials are widely available, and the preparation process is simple and the reproducibility is high; the properties of high film formation uniformity and so on. The above novel membrane materials only have one or several characteristics, while other property levels are generally or very low so that various application fields of the FO membrane are limited and the industrialization by mass production is scarce. Therefore, based on the above problems, the development of FO membrane materials still requires further research and new thoughts.

Currently, the development and commercialization of the FO membranes is mainly occurring in the USA and Denmark. Especially, the Hydro Technology Innovations (HTI) Company in the USA started the earliest. Its membranes Sheet samples were most frequently experimented by researchers worldwide as the FO membrane materials in their studies. The HTI began to apply the FO technology in NASA, the USA Department of Defense, branches of the USA military, and in aid of relief organizations around the world in 2002. The draw solute of the application was sugar, and the DS can be directly 
utilization by humans for drinking [55]. At the same time, HTI applied in the hydraulic fracturing industry, which can recover $80 \%$ of the drilling wastewater for reuse [56]. In the Water Management and Reuse Centre of the University of South Australia, a pilot study was conducted based on TFC-FO of HTI and the DS was recovered by RO [14]. The company Oasys Water in the USA developed a polyamide TFC membrane in 2008 and pushed it into commercial and engineering applications. In 2013, an integrated FO system was launched by the Oasys with heat recoverable $\left(\mathrm{NH}_{4}\right)_{2} \mathrm{CO}_{3}$ and $\mathrm{NH}_{4} \mathrm{HCO}_{3}$ as the draw solutes. Meanwhile, the company used brine as a draw solute for highly saline water desalination in Permian Basin and Marcellus Shale Project.

In 2017 Oasys Water and Beijing Woteer have partnered to treat and recover the large quantity of wastewater produced by the Zhongtian Hechuang Energy Corporation, currently the world's largest coal-to-olefin project. In order to achieve zero liquid discharge as mandated by regional authorities [57]. Oasys Water's award-winning ClearFlo Membrane Brine Concentrator (MBCTM) and Beijing Woteer's completed pretreatment system work together to process $5760 \mathrm{~m}^{3} / \mathrm{d}$ of wastewater.

In 2010, the installations of the FO-RO system were completed in Oman and Gibraltar, and a $200 \mathrm{~m}^{3} / \mathrm{d}$ desalination plant was established in Al Naghdah [55].

In 2015, Aquaporin in Denmark developed the AQP aquaporin membrane and launched a new hollow fiber FO membrane in 2017. Trevi System Inc. in California was established five pilot-scale in the US and the Middle East since 2010 to demonstrate the FO system based on the CA membranes [58]. The systems were taken soluble polymers as the DS, and two-stage NF to recovery the DS [1].

Although there are many references on the preparation of the FO membranes in the literature, currently there are still only a few global FO membrane suppliers, and the products of most companies are still in the research and development stage, as shown in Table 1. Therefore, the commercialization and engineering application of the FO membranes still need further development for a long way.

Table 1. List of commercial membrane products.

\begin{tabular}{|c|c|c|c|c|}
\hline Company & Country & Material and Type & Configuration & Status \\
\hline Aquaporin A/S (AQP) & Denmark & Biomimetic aquaporin & $\begin{array}{l}\text { Hollow fiber and } \\
\text { flat sheet }\end{array}$ & Commercial \\
\hline $\begin{array}{l}\text { Hydration Technology } \\
\text { Innovations (HTI) }\end{array}$ & USA & Cellulose tri-acetate TFC & Flat sheet & $\begin{array}{l}\text { Small scale } \\
\text { application }\end{array}$ \\
\hline Oasys Water & USA & TFC & Flat sheet & $\begin{array}{l}\text { Engineering } \\
\text { application }\end{array}$ \\
\hline $\begin{array}{l}\text { Fluid Technology } \\
\text { Solutions Inc. }\end{array}$ & USA & Cellulose tri-acetate & Flat sheet & Development \\
\hline Nitto Denko & Japan & Composite membrane & $\begin{array}{l}\text { Hollow fiber and } \\
\text { flat sheet }\end{array}$ & Commercial \\
\hline $\begin{array}{c}\text { Woongjin Chemical Co. } \\
\text { Ltd. }\end{array}$ & Korea & Composite membrane & $\begin{array}{l}\text { Hollow fiber and } \\
\text { flat sheet }\end{array}$ & Commercial \\
\hline Samsung Co. Ltd. & Korea & Composite membrane & Flat sheet & Development \\
\hline
\end{tabular}

\section{Draw Solutes of FO}

Since the osmotic pressure is the only driving force of the FO process, the choice of the draw solute is one of the decisive factors that influence the performance of the process. Suitable DS should have the following characteristics: providing high osmotic pressure, easy accessibility, stable property and simple, energy-saving recovery methods.

At present, there are many kinds of DS applied in the process of FO, which is generally classified into inorganic salts, organic polymers, magnetic nanoparticles, hydrogels, and ionic liquids.

\subsection{Inorganic Salts}

Among inorganic salts, sodium chloride is regarded as the most widely used draw solute because of its high solubility, high osmotic pressure, low price, wide source, and negligible toxicity [59]. 
However, sodium chloride at the same ionic molar concentration has a lower osmotic pressure than potassium chloride. Second, the low molecular weight of sodium chloride is prone to RO and the RSF is high, resulting in loss of draw solute in the solution, reduction of osmotic pressure difference, FS pollution, and others passive effects on the FO process. Third, the sodium chloride solute recovery methods mainly include distillation, $\mathrm{RO}$, electrodialysis, etc., and the recovery methods consume high amounts of energy.

Because of the defects of sodium chloride as previously mentioned, which the recovery methods are energy-consuming, people have successfully developed other draw solutes to overcome the barrier. Due to its poor thermal stability, it can be decomposed mostly into carbon dioxide and ammonia at $60{ }^{\circ} \mathrm{C}$ under atmospheric pressure, hence it is easy to acquire fresh water with it as liquid solute. Based on the above characteristics, it is also widely used in the fields of seawater desalination research and industrial wastewater treatment.

P. Zhao [60] studied the performance comparison of anion and cation in the FO process of eight commonly utilized inorganic draw solutes, $\mathrm{NaCl}, \mathrm{NaNO}_{3}, \mathrm{KCl}, \mathrm{KNO}_{3}, \mathrm{NH}_{4} \mathrm{Cl}_{2} \mathrm{NH}_{4} \mathrm{NO}_{3}, \mathrm{CaCl}_{2}$, and $\mathrm{Ca}\left(\mathrm{NO}_{3}\right)_{2}$, respectively.

Jiang et al. [61] used a $4 \mathrm{~mol} / \mathrm{L}(\mathrm{M})$ ammonium bicarbonate solution as DS to recover freshwater from the oil sand wastewater. The recovery rate was $85 \%$, and the rejection rate of ion contaminants reached $80-100 \%$. Oasys Corporation of the United States uses ammonium bicarbonate solution as FO DS in the development of shale gas in the Permian Basin of the United States to treat petrochemical wastewater, achieving zero emission of wastewater, and the quality of effluent can meet drinking water standards.

However, studies have shown that the ammonium ion in ammonium bicarbonate has a small difference in hydration radius and water molecules, resulting in the interception performance of the draw solute is undesirable, the RSF is relative intolerable and contaminates the FS, which limits its applications.

\subsection{Organics and Polymers}

The organic polymer was also applied as a draw solute in FO processes research. R. E. Kravath and J. A. Davis [62] proposed glucose and fructose as draw solutes in 1975. The diluted DS can be directly drank, eliminating the recovery process of the draw solute, reducing energy consumption, and was widely applied in water recycling usage of the aerospace field. Phuntshon et al. [63] used fertilizer as a draw solute to treat brackish water. The diluted DS can directly irrigate farmland, eliminating the need for recovery.

Ge [64] employed 1.0 M oxalic acid complex with the formula of $\mathrm{Na}-3\left[\mathrm{Cr}\left(\mathrm{C}_{2} \mathrm{O}_{4}\right)_{(3)}\right](\mathrm{Na}-\mathrm{Cr}-\mathrm{OA})$ as a draw solute, and recovered fresh water from raw water of high As(III) concentration with $1000 \mathrm{ppm}$ at $60{ }^{\circ} \mathrm{C}$, the relatively high water flux of $28 \mathrm{~L} /\left(\mathrm{m}^{2} \cdot \mathrm{h}\right)(\mathrm{LMH})$ in FO mode and $74 \mathrm{LMH}$ in pressure delay infiltration (PRO) mode are achieved. Recovery rates of $21.6 \%$ (FO mode) and $48.3 \%$ (PRO mode) were also completed within $2 \mathrm{~h}$.

P. Zhao [60] employed a molecular weight of 3,000,000 polyacrylamide as a draw solution to study the FO performance in different modes, and further applied in dye wastewater treatment. It is concluded that polyacrylamide can be used as a draw solution for the FO process as it had very high molecular weight, long molecular chain length, the RSF was very low and almost zero. Polyacrylamide also had well stability. However, the water solubility of polyacrylamide was poor because of the molecular structure, especially high molecular weight polyacrylamide, which is gelatinous in aqueous solution. With other equivalent conditions, the ionic polyacrylamide has a higher osmotic pressure than the nonionic aqueous solution. However, due to the molecular structure and polarity of polyacrylamide, the osmotic pressure of the aqueous solution is much lower than that of the inorganic salt aqueous solution, so the membrane flux is much lower than that with the inorganic salt aqueous solution is used in FO process. 


\subsection{Magnetic Nanoparticles}

As the traditional draw solutes cannot meet all requirements-such as low price, wide source, low concentration, and high osmotic pressure, recycle process easily and energy saving-researchers have set off a new wave of drivers, a large number of new draw solutes have been investigated and developed, such as magnetic nanoparticle, hydrogel, ionic liquid, etc.

Mishra [65] utilized polyethylene glycol and polyacrylic acid in contact with metal precursors to prepare hydrophilic magnetic nanoparticles, which were prepared by polyol and thermal decomposition process and with higher osmotic pressure and better water dispersion. Chi [66] exploited oleic acid to modify $\mathrm{Fe}_{3} \mathrm{O}_{4}$ magnetic nanoparticles (MNPs) as a draw solute and applied to FO, the recovery rate of MNPs was up to $85 \%$.

The magnetic nanoparticle (MNPs) RSF is prominent perfect, close to zero. It used in the area where the RSF requirements are critical strict, such as protein and drug enrichment applications. Compared with $\mathrm{NaCl}, \mathrm{MNPs}$ have the poorer water flux and are potential failure to agglomeration. Although magnetic nanoparticles have these advantages as aforementioned, the preparation process of MNPs was relatively complicated and the raw material costly, on the other hand, the stability of some specific MNPs is generally weak and easy to decompose, which cause contamination of the recovered freshwater and the loss of draw solutes.

\subsection{Hydrogels and Ionic Liquids}

The hydrogel polymer contains a large number of hydrophilic groups, which helps it to acquire a good ability to extract fresh water, and the ionic group carried by the hydrogel polymer can provide a high osmotic pressure. Moreover, the hydrogel polymer can be separated from water with the alteration of external conditions, e.g., temperature, light, and pressure. Due to the unique structural characteristics and overall performance, porous hydrogels have become an interesting focus in the research development of draw solutes in recent years. At present, the main preparation methods can be classified into freeze-drying porogen, phase separation, template, and interpenetrating polymer network, etc. Consequently, it becomes a research central issue of new types of DS.

Li [67] prepared sodium polyacrylate (PSA), sodium polyacrylate and sodium $\mathrm{N}$-isopropyl acrylate copolymer (PSA-PINPAM), polyacrylamide (PAM) and N-isopropyl acrylamide (PNIPAM), and finally revealed that PSA-PINPAM has the highest water flux and recovery efficiency.

Cai [68] prepared the PSA-PNIPAM and PVA-PINPAM of the semi-interpenetrating network structure as FO draw solutes. Cai also demonstrated that PVA-PINPAM has higher water flux, the separation of water and extractant can be achieved by heating, the recovery efficiency is higher at the same temperature than that of the PSA-PNIPAM.

In recent years, variable polarity solution, zwitterionic material, surfactant solution, etc. have also been proposed and studied. The characteristics and properties of the draw solute are mentioned and explained in literature. The types and methods of recovery and the advantages and disadvantages of various driving agents are also listed in Table 2. 
Table 2. Overview of development and recovery approaches to draw solutes used in FO technology.

\begin{tabular}{|c|c|c|c|c|c|}
\hline Year & Researchers & Draw Solutes & $\begin{array}{l}\text { Methods of } \\
\text { Recovery }\end{array}$ & Drawbacks & Ref. \\
\hline 2014 & Lutchmiah & Zwitterionic & NF & $\begin{array}{l}\text { High Energy } \\
\text { Consumption * }\end{array}$ & [69] \\
\hline 2015 & Zhang & $\begin{array}{c}\text { Polyvinyl alcohol(PVA), } \\
\text { Polymeric electro sensitive gel }\end{array}$ & Electric field & Energy intensive & {$[70]$} \\
\hline 2015 & Boo & $\begin{array}{l}\text { Trimethylamine-carbon } \\
\text { dioxide }\end{array}$ & $\begin{array}{l}\text { Heating low } \\
\text { temperature }\end{array}$ & Energy intensive & [71] \\
\hline 2015 & Zhao Pin & Hydrolyzed polyacrylamide & Utilization directly & $\begin{array}{l}\text { Very large viscosity Poor } \\
\text { water flux }\end{array}$ & {$[72]$} \\
\hline 2016 & Mishra & MNPs & $\begin{array}{l}\text { Magnetic field } \\
\text { recovery }\end{array}$ & $\begin{array}{l}\text { Preparation complicated, } \\
\text { raw material costly }\end{array}$ & {$[65]$} \\
\hline 2017 & Chi & Modify $\mathrm{Fe}_{3} \mathrm{O}_{4}$ & $\begin{array}{l}\text { Magnetic field } \\
\text { recovery }\end{array}$ & $\begin{array}{l}\text { Preparation complicated, } \\
\text { raw material costly }\end{array}$ & {$[66]$} \\
\hline 2017 & Huang & $\begin{array}{c}\text { Poly (4-styrenesulfonic } \\
\text { acid-co-maleic acid) sodium }\end{array}$ & NF & $\begin{array}{l}\text { High energy } \\
\text { consumption }\end{array}$ & [73] \\
\hline 2017 & Kim & Fertilizer & NF & $\begin{array}{l}\text { High energy } \\
\text { consumption }\end{array}$ & {$[74]$} \\
\hline 2017 & $\mathrm{Li}$ & Fertilizer & Not studies & $\begin{array}{l}\text { Not pure water, small } \\
\text { reuse area }\end{array}$ & [12] \\
\hline 2017 & Yang & $\begin{array}{l}\text { Polyacrylic acids sodium } \\
\text { (PAA) with different MWs }\end{array}$ & $\begin{array}{l}\text { Protonated and } \\
\text { Deprotonated by } \\
\text { pH adjustment, MF }\end{array}$ & Complicated procedures & {$[75]$} \\
\hline 2017 & Yu & $\begin{array}{l}\text { Sodium alginate grapheme } \\
\text { oxide (SA-GO) }\end{array}$ & $\begin{array}{l}\text { Low-strength } \\
\text { mechanical } \\
\text { compression }\end{array}$ & Poor water flux & [8] \\
\hline 2018 & Chen & $\begin{array}{c}{\left[\mathrm{N}-\left(\mathrm{CH}_{3}\right)_{4}\right]_{3}\left[\mathrm{Cr}\left(\mathrm{C}_{2} \mathrm{O}_{4}\right)_{3}\right]} \\
\left(\mathrm{NMe}_{4}-\mathrm{Cr}-\mathrm{OA}\right)\end{array}$ & MD & $\begin{array}{l}\text { High energy } \\
\text { consumption }\end{array}$ & {$[76]$} \\
\hline 2018 & Jeongseon & Ammonium iodide, salts & $\begin{array}{l}\text { Heating and } \\
\text { cooling }\end{array}$ & High RSF, toxic, volatile & [77] \\
\hline 2019 & Wang & EDTA-Na-2, & MF & Toxic & [78] \\
\hline 2019 & Muhammad & $\begin{array}{c}\text { Ammonium sulphate, } \\
\text { potassium hydrogen } \\
\text { phosphate and } \\
\text { Mono-ammonium phosphate }\end{array}$ & / & High RSF & [79] \\
\hline 2019 & Kim & $\operatorname{NaCl}(1,2,3 \mathrm{M})$, glucose & $\begin{array}{c}\text { NF } \\
\text { Utilization directly }\end{array}$ & $\begin{array}{c}\text { Energy intensive Not } \\
\text { pure water, small reuse } \\
\text { area }\end{array}$ & {$[80]$} \\
\hline 2019 & Gimun & Monoethanolamine (MEA) & MD & $\begin{array}{l}\text { High energy } \\
\text { consumption }\end{array}$ & [81] \\
\hline 2019 & Mattia & $\mathrm{MgCl}_{2}$ and $\mathrm{Na}_{2} \mathrm{SO}_{4}$ & NF & $\begin{array}{l}\text { High energy } \\
\text { consumption }\end{array}$ & {$[82]$} \\
\hline 2019 & Zeng Jian & $\begin{array}{c}\text { Multi-layer } \\
\text { temperature-responsive } \\
\text { hydrogel }\end{array}$ & $\begin{array}{l}\text { Temperature } \\
\text { change }\end{array}$ & Complicated preparation & [83] \\
\hline 2019 & R. Lambrechts & Fertilizer & Utilization directly & $\begin{array}{l}\text { Not pure water, small } \\
\text { reuse area }\end{array}$ & {$[84]$} \\
\hline
\end{tabular}

\section{Application in Wastewater Treatment}

Although a wide range of applications of FO has been reported, including seawater/brackish water desalination, wastewater treatment and reuse, food processing and power generation, wastewater 
treatment and reuse attracts more attention [86]. This review mainly discusses the recent advantages of wastewater treatment.

Recently, research on FO application on wastewater treatment can be divided into two clusters, (i) FO and FO-based hybrid system and (ii) integrated FO system. In FO and FO-based hybrid systems, the function of the FO membrane is freshwater recovery and pollutant rejection from FS. Although another subsequent process is the need for recycling the freshwater from the diluted DS, the FO is studied independently in the hybrid process. In the integrated FO system, the FO membrane is usually used to replace the conventional membrane in the bioreactor, such as the FO membrane in MBR. The role of the membrane is to concentrate the wastewater and enhance the performance of the modified system.

Therefore, FO has shown broad application prospects in wastewater treatment and reuse, seawater desalination, resource recovery, and food and medicine manufacturing as shown in Table 3.

Table 3. List of the application of FO in different fields.

\begin{tabular}{|c|c|c|c|c|c|c|}
\hline & eld & FS & DS & Process & Performance $L /\left(\mathrm{m}^{2} \cdot \mathrm{h}\right)$ & Ref. \\
\hline \multirow{4}{*}{$\begin{array}{l}\text { Wastewater } \\
\text { treatment and } \\
\text { reuse }\end{array}$} & $\begin{array}{c}\text { Tannery } \\
\text { wastewater }\end{array}$ & $\begin{array}{c}\text { Tannery } \\
\text { wastewater }\end{array}$ & $\begin{array}{l}0.8 \mathrm{M}(\mathrm{mol} / \mathrm{L}) \\
\mathrm{NaCl} \text { solution }\end{array}$ & $\mathrm{FO}+\mathrm{NF}$ & $52-55$ & [87] \\
\hline & $\begin{array}{l}\text { High-salinity } \\
\text { oil-bearing } \\
\text { wastewater }\end{array}$ & $\begin{array}{l}\text { Oil-bearing } \\
\text { wastewater }\end{array}$ & $3 \mathrm{M} \mathrm{NaCl}$ & $\mathrm{FO}$ & 29 & [88] \\
\hline & $\begin{array}{l}\text { Oil sands tailings } \\
\text { water }\end{array}$ & OSPW & $\begin{array}{c}\text { basal } \\
\text { depressurization } \\
\text { water }\end{array}$ & FO & $\begin{array}{l}\text { Wastewater volume } \\
\text { decreased }>40 \%, 3\end{array}$ & [89] \\
\hline & $\begin{array}{l}\text { Molasses distillery } \\
\text { wastewater }\end{array}$ & $\begin{array}{c}\text { Distillery } \\
\text { wastewater }\end{array}$ & $3 \mathrm{M} \mathrm{MgCl}_{2} \cdot 6 \mathrm{H} 2 \mathrm{O}$ & / & 2.8, Water recovery $70 \%$ & [50] \\
\hline \multirow{3}{*}{$\begin{array}{l}\text { Resource } \\
\text { Recovery }\end{array}$} & $\begin{array}{l}\mathrm{P} \text { and } \mathrm{N} \text { recovery } \\
\text { from urine }\end{array}$ & Fresh urine & $\begin{array}{l}\text { Mg-based } \\
\text { fertilizer DS }\end{array}$ & FO & $\begin{array}{l}\text { Recovered about } 40 \% \text { of } \\
\text { the } \mathrm{P} \text { and } 50 \% \text { of the } \mathrm{N}\end{array}$ & [90] \\
\hline & $\begin{array}{l}\text { Precious metal } \\
\text { recovery }\end{array}$ & $\begin{array}{l}\text { Pd ion waste } \\
\text { solution }\end{array}$ & $\begin{array}{l}\text { Electroless (E'less) } \\
\text { nickel }(\mathrm{Ni}) \text { waste } \\
\text { solution }\end{array}$ & FO & $\begin{array}{c}\text { Concentrated Pd by } 17.2 \\
\text { times }\end{array}$ & [91] \\
\hline & Energy recovery & $\begin{array}{l}\text { Synthetic } \\
\text { wastewater }\end{array}$ & $\begin{array}{l}2 \mathrm{M} \text { magnesium } \\
\text { acetate }\end{array}$ & AnOMEBR & $\begin{array}{c}0.537 \mathrm{~kJ} \text { per day positive } \\
\text { energy }\end{array}$ & [19] \\
\hline $\begin{array}{c}\text { Seawater } \\
\text { desalination }\end{array}$ & / & $\begin{array}{l}\text { Power plant } \\
\text { wastewater }\end{array}$ & seawater & $\mathrm{FO}+\mathrm{RO}$ & $8 \pm 1$ & [46] \\
\hline \multirow{3}{*}{$\begin{array}{l}\text { Food and } \\
\text { medicine } \\
\text { manufacturing }\end{array}$} & / & $\begin{array}{l}\text { Sucrose and } \\
\text { pectin }\end{array}$ & $\mathrm{NaCl}, 6 \mathrm{M}$ & $\begin{array}{l}\text { Ultrasonic + } \\
\text { FO }\end{array}$ & $\begin{array}{l}\text { Mitigated the external } \\
\text { concentration } \\
\text { polarization on feed side, } \\
\text { Enhanced the average } \\
\text { rate of water flux }\end{array}$ & [92] \\
\hline & l & $\begin{array}{l}\text { Sugarcane } \\
\text { juice }\end{array}$ & Sea bittern & $\mathrm{FO}$ & $\begin{array}{c}\text { 4-fold concentration of } \\
\text { sucrose was achieved, }< \\
3 \% \text { sucrose loss. }\end{array}$ & [93] \\
\hline & / & protein & $\begin{array}{l}\text { Superabsorbent } \\
\text { polymer(SAP) } \\
\text { hydrogels }\end{array}$ & $\mathrm{FO}$ & $\begin{array}{l}\text { Hydrogels with } 8.6 \text { wt } \% \\
\text { of epichlorohydrin } \\
\text { crosslinker, Showed } \\
\text { maximum swelling ratios }\end{array}$ & [94] \\
\hline
\end{tabular}

\subsection{FO and FO-Based Hybrid System}

Due to the advantages of FO such as low hydraulic pressure and low energy consumption, this economically feasible and technically sound technology has been widely investigated in the application of seawater desalination. Under the osmosis pressure provided by the appropriate DS, water can be forced through the membrane from seawater to DS. With regeneration methods, desalinated water can be produced. Similarly, the benefits of FO also work for the treatment of wastewater with a high concentration of pollutants. The water is drawn from the wastewater leading to the reduction of wastewater volume. Meanwhile, the pollutants are effectively rejected by the FO membrane. 
To effectively reduce the volume of wastewater, increasing numbers of studies are focused on improving FO efficiency. The solute and concentration of DS, pollutant composition of FS and membrane properties are all factors affecting the FO process efficiency [95]. The driving osmosis pressure provided by DS is decided by the solute and concentration. The pollutant composition of FS mainly affects the membrane fouling propensity and the reduction of water flux. The membrane property is one of the most important factors that influence the $\mathrm{FO}$ performance. $\mathrm{NaCl}$ is the most frequently used DS solute which can provide high osmotic pressure. The performance reached $23.4 \mathrm{~L} /\left(\mathrm{m}^{2} \cdot \mathrm{h}\right)(\mathrm{LMH})$ when $1 \mathrm{M} \mathrm{NaCl}$ was used as $\mathrm{DS}$ to treat simulated radioactive wastewater at AL-DS [95]. The high flux may contribute to the FS which is $0.5-20 \mathrm{mg} / \mathrm{L} \mathrm{CoCl} 2$ solution, not the real wastewater. To treat spent electroless nickel plating baths and recover nickel, a high-performance CTA FO membrane with a thickness of $50.0 \pm 0.5 \mu \mathrm{m}$ was investigated [96]. Water flux reached $13 \mathrm{LMH}$ and $\mathrm{NiSO}_{4} \cdot 6 \mathrm{H}_{2} \mathrm{O}$ crystals occurred in the FS using $5 \mathrm{M} \mathrm{NaCl}$ as DS. FO provided a new method to treat harmful plating solution or wastewater. Also, the FO process showed significant performance in oil exploitation wastewater treatment which has high viscosity and high salinity [88]. 99\% salt and 96\% oil were rejected by the TFC membrane in the optimized operating conditions (cross-flow velocity $15 \mathrm{~cm} / \mathrm{s}$, $3 \mathrm{M} \mathrm{NaCl}$ solution as the DS and temperature was $25^{\circ} \mathrm{C}$ ). $\mathrm{FO}$ technology was proved to be feasible for the oilfield produced wastewater from polymer flooding with the oil concentration ranging from 100 to $700 \mathrm{mg} / \mathrm{L}$. Furthermore, simultaneous water reuse from wastewater and the production of nutrient solution for hydroponic applications were achieved through the FDFO process [97]. Ammonium sulfates showed a high water recovery rate, up to $76 \%$ after 4 days of operation. Other applications of the FO process on wastewater treatment were tested to concentrate sugarcane molasses distillery wastewater [50] and digester centrate [98].

The solute of DS can be recovered through other post-treatment processes. In Ashley's review, the post-treatment technologies were divided into three kinds: pressure driven RO or NF, thermally driven MD and electrically driven ED [99]. FO + NF hybrid system was studied for the treatment of tannery wastewater where the high flux (52 LMH) and rejection ( $98.5 \%$ of COD, $97.2 \%$ of chlorides and $98.2 \%$ ofsulfate) were achieved [87]. The diluted DS was dewatered through NF with a $\mathrm{NaCl}$ rejection of $98.5 \%$. In the $\mathrm{FO}+\mathrm{RO}$ hybrid process for coal-fired power plant wastewater treatment and reuse, seawater after UF was used as DS [46]. The average water flux of the pilot FO process was $10.6 \pm 0.1 \mathrm{LMH}$ during the summer which was $30 \%$ greater than that during winter. Notably, the total energy consumption of the FO + RO hybrid system was $15 \%$ less than that of a typical seawater desalination $\mathrm{RO}$ process. To treat high salinity hazardous waste landfill leachate, a vapor pressure driving FO-MD process were investigated [100]. The FO rejection rates of TOC, TN and $\mathrm{NH}_{4}{ }^{+}-\mathrm{N}$ were $92.04 \%, 94.07 \%$, and $97.99 \%$. Meantime, high rejection rates of heavy metal ions could be obtained by the MD process. The combination of the advantages of these two processes guaranteed the high quality effluent of the FO-MD hybrid system. Similar performance could also be seen in the application of dairy wastewater and grain possessing wastewater treatment [101,102]. As an alternative membrane technology, electrodialysis (ED) is a membrane-based separation process in which ions across ion-selective membranes under an electric field [103]. Since ED can only remove ionized species, it is typically used to desalinate high-salinity seawater or wastewater. Zou and He [104] demonstrated the feasibility of the FDFO-ED hybrid system for wastewater reuse and mitigation of salinity buildup on the feed side. $96.6 \pm 3.0 \%$ reverse-fluxed DAP in FO was successfully recovered under 3.0 V 1-h daily operation. The overview of FO and FO based hybrid system pilot application was showed in Table 4.

It was shown that most of the projects still used brine or sodium chloride as the DS, which may be due to the higher osmotic pressure of the DS at the same quality and available easily and widely. The permeate flux was also comparably ranging from 4.65 LMH-17LMH. In Project 9, applying a pressure of 1.6 bar on the feed water side could reach a maximum flux of $52 \mathrm{LMH}$. Many types of wastewater treated in the FO projects were listed, including domestic sewage, industrial wastewater, 
landfill leachate, and so on. The status demonstrated that the FO process can be applied in a wide range of situations and achieve promising results.

Table 4. Overview of FO and FO based hybrid system pilot application.

\begin{tabular}{|c|c|c|c|c|c|c|}
\hline NO. & Process & DS & Membrane & FS & Performance & Ref. \\
\hline 1 & $\mathrm{FO}$ & $3 \mathrm{M} \mathrm{MgCl}_{2} \cdot 6 \mathrm{H}_{2} \mathrm{O}$ & $\begin{array}{l}\text { TFC membrane } \\
\text { from Aquaporin }\end{array}$ & $\begin{array}{c}\text { Sugarcane } \\
\text { molasses distillery } \\
\text { wastewater }\end{array}$ & 7.6 LMH & [50] \\
\hline 2 & $\mathrm{FO}$ & fertilizer chemicals & $\begin{array}{l}\text { TFC membrane } \\
\text { from Toray Inst. } \\
\text { Inc. }\end{array}$ & $\begin{array}{l}\text { Municipal } \\
\text { wastewater }\end{array}$ & 13.2-21.1 LMH & [97] \\
\hline 3 & $\mathrm{FO}$ & $5 \mathrm{M} \mathrm{NaCl}$ & CTA membrane & $\begin{array}{l}\text { Spent electroless } \\
\text { nickel plating } \\
\text { baths }\end{array}$ & $13 \mathrm{LMH}$ & [96] \\
\hline 4 & FO & $1 \mathrm{M} \mathrm{NaCl}$ & $\begin{array}{l}\text { TFC membrane } \\
\text { from HTI }\end{array}$ & $\begin{array}{l}\text { Simulated } \\
\text { radioactive } \\
\text { wastewater } \\
\end{array}$ & $23.4 \pm 2.5 \mathrm{LMH}$ & [95] \\
\hline 5 & $\mathrm{FO}$ & $3 \mathrm{M} \mathrm{NaCl}$ & TFC membrane & HSOB wastewater & $\begin{array}{l}29 \mathrm{LMH}, 99 \% \text { salt and } \\
96 \% \text { oil rejection rate }\end{array}$ & [88] \\
\hline 6 & $\mathrm{FO}$ & BDW & $\begin{array}{l}\text { CTA membrane } \\
\text { from HTI }\end{array}$ & OSPW & $\begin{array}{l}40 \% \text { of OSPW volume } \\
\text { reduced }\end{array}$ & [89] \\
\hline 7 & $\mathrm{FO}$ & $10 \% \mathrm{NaCl}$ & $\begin{array}{l}\text { TFC membrane } \\
\text { from HTI }\end{array}$ & $\begin{array}{c}\text { Coal gasification } \\
\text { wastewater }\end{array}$ & $17 \mathrm{LMH}$ & {$[105]$} \\
\hline 8 & $\mathrm{FO}$ & seawater & $\begin{array}{l}\text { TFC membrane } \\
\text { from Porifera }\end{array}$ & Digester centrate & $5 \mathrm{LMH}$ & [98] \\
\hline 9 & $\mathrm{FO}+\mathrm{NF}$ & $0.8 \mathrm{M} \mathrm{NaCl}$ & $\begin{array}{l}\text { TFC membrane } \\
\text { from } \\
\text { sepromembranes }\end{array}$ & $\begin{array}{c}\text { Tannery } \\
\text { wastewater }\end{array}$ & $\begin{array}{c}52 \mathrm{LMH} \text { at } 1.6 \mathrm{bar} \\
\text { pressure, rejection } \\
\text { (98.5\% of COD, } 97.2 \% \text { of } \\
\text { chlorides and } 98.2 \% \text { of } \\
\text { sulphate) }\end{array}$ & [87] \\
\hline 10 & FO-RO & Seawater after UF & $\begin{array}{l}\text { an active PA layer } \\
\text { with an } \\
\text { embedded, } \\
\text { polyester mesh } \\
\text { support(PFO-100 } \\
\text { from Hayward) }\end{array}$ & $\begin{array}{l}\text { Coal-fired power } \\
\text { plant wastewater }\end{array}$ & $\begin{array}{c}\text { Average water flux } 10.6 \\
\pm 0.1 \mathrm{LMH}\end{array}$ & [46] \\
\hline 11 & $\mathrm{FO}+\mathrm{MD}$ & $4.82 \mathrm{M} \mathrm{NaCl}$ & $\begin{array}{l}\text { TFC membrane } \\
\text { from HTI }\end{array}$ & Landfill leachate & $4.65 \mathrm{LMH}$ & {$[100]$} \\
\hline 12 & $\mathrm{FO}+\mathrm{MD}$ & $\mathrm{NaCl}$ & $\begin{array}{l}\text { CTA membrane } \\
\text { from HTI }\end{array}$ & Dairy wastewater & $9.79 \mathrm{LMH}$ & {$[101]$} \\
\hline 13 & $\mathrm{FO}+\mathrm{MD}$ & $\begin{array}{l}20 \% \text { TDS hypersaline } \\
\text { brine }\end{array}$ & $\begin{array}{l}\text { Aquaporin flat } \\
\text { sheet membrane } \\
\text { from Sterlitech }\end{array}$ & $\begin{array}{l}\text { Grain possessing } \\
\text { wastewater }\end{array}$ & $15 \mathrm{LMH}$ & [102] \\
\hline 14 & $\begin{array}{l}\mathrm{FDFO}+ \\
\mathrm{ED}\end{array}$ & $1 \mathrm{M}$ DAP & $\begin{array}{l}\text { CTA membrane } \\
\text { from HTI }\end{array}$ & $\begin{array}{c}\text { Treated } \\
\text { wastewater } \\
\text { (secondary } \\
\text { effluent) }\end{array}$ & $\begin{array}{l}151.3 \mathrm{~mL} \text { water } \\
\text { recovery on the first day }\end{array}$ & {$[104]$} \\
\hline
\end{tabular}

\subsection{Integrated FO System}

The integrated FO system is constituted of FO membrane and membrane-based biological wastewater treatment technology. The integrated FO system include osmotic microbial fuel cell (OsMFC) and osmotic membrane bioreactor (OMBR). Recent literature have elucidated the integration of osmosis in MFC and MBR for simultaneous recovery of osmotic water, the concentration of wastewater, and the improvement of effluent quality through the application of the FO membrane $[106,107]$. 


\subsubsection{OsMFC}

MFC is one of the most economical alternative solutions for clean energy production by digesting biodegradable organics present in wastewater [108]. A proton exchange membrane is placed between anode and cathode. The produced protons in the anode chamber are forced to migrate to the cathode surface under the proton motive force throughout the membrane [109]. Despite the high potential to recover clean energy, further development of MFC is hurdled by the low potential to produce high quality effluent and low electricity production [110]. Therefore, given the distinct advantages of high rejection, low fouling propensity, and low energy consumption, FO is integrated with MFC to achieve benefits on wastewater treatment, freshwater extraction and clean energy recovery, and the proton exchange membrane is replaced by the FO membrane here.

\subsubsection{OMBR}

Membrane bioreactor (MBR), which has been used for over 50 years, is an integration of membrane process for solid liquid separation and conventional activated sludge wastewater treatment. Flat or hollow fiber MF and UF are commonly used membranes in MBR.

Besha et al. [111] reviewed the advantages of MBR compared with conventional activated sludge process including high effluent quality, decreased reactor volume, elevated solid retention time (SRT) and high MLSS, low sludge yield, and easier operation.

However, there are still some restrictions associated with this widely used technology including membrane fouling, high energy consumption and low removal efficiency of poorly biodegradable micropollutants like diclofenac, atrazine, and carbamazepine [112-115]. For high quality effluent, a novel MBR — named osmosis membrane bioreactor (OMBR) - has been developed and widely studied to promote wastewater treatment and reuse. In OMBR, FO membrane module is displaced in the wastewater. Combined with biological treatment, water from the mixed liquor is forced to transfer through the semipermeable membrane to the draw side under the osmotic pressure gradient. The pollutants, activated sludge and solids are all rejected by the membrane. The superior performance of OMBR over conventional MBR has been demonstrated in previous research [116,117].

However, OMBR still has some deficiencies, such as salinity accumulation and FO membrane fouling. The salinity accumulation is mainly caused by the high retention efficiency of the FO membrane to the FS and the RSF. The salinity accumulation of the OMBR system will reduce the water flux of the FO membrane, aggravates the membrane fouling, and affects the organism activities of the activated sludge. Therefore, reducing salinity accumulation is critical for the OMBR system. In order to alleviate the salinity issue, one of the most common methods is to discharge the high salinity liquid, it means that to reduce the sludge residence time (SRT). Therefore, a short SRT helps to alleviate the accumulation of salinity. The SRT will correspondingly reduce the sludge concentration (MLSS) and affect the system operation. Therefore, the contradiction between ease of salinity accumulation and acquisition of proper concentration of biomass remains a bottleneck obstacle.

Zhu Wenjun [107] utilized an integrated UF or MF membrane system in the OMBR system to remove the soluble inorganic salts in the reactor. This process has a longer SRT than the traditional OMBR system, so a higher sludge concentration can be obtained. Recent integrated FO systems mentioned in references were listed in Table 5. 
Table 5. List of recent integrated FO system mentioned in references.

\begin{tabular}{|c|c|c|c|c|c|c|c|}
\hline NO. & Process & Purpose & DS & Membrane & FS & Performance & Ref. \\
\hline 1 & OsMFC & $\begin{array}{l}\text { Improve bioenergy } \\
\text { and water recovery }\end{array}$ & $\begin{array}{c}\text { Seawater, } \\
35 \pm 2 \mathrm{~g} / \mathrm{L} \\
\mathrm{NaCl}\end{array}$ & $\begin{array}{l}\text { CTA membrane } \\
\text { from HTI }\end{array}$ & $\begin{array}{c}\text { Domestic } \\
\text { wastewater }\end{array}$ & $\begin{array}{c}\text { Maximum power density of } \\
28.90 \mathrm{~W} / \mathrm{m}^{3} \mathrm{NCC} \text { and } 363 \pm \\
8 \% \text { of COD removal }\end{array}$ & {$[110]$} \\
\hline 2 & OsMFC & $\begin{array}{l}\text { Ammonium } \\
\text { removal }\end{array}$ & $\begin{array}{l}35 \mathrm{~g} / \mathrm{L} \\
\mathrm{NaCl}\end{array}$ & $\begin{array}{l}\text { TFC membrane } \\
\text { from HTI }\end{array}$ & $\begin{array}{c}\text { Synthetic } \\
\text { wastewater }\end{array}$ & $\begin{array}{l}55.2 \pm 6.5 \% \text { higher } \\
\text { ammonium removal }\end{array}$ & {$[106]$} \\
\hline 3 & $\mathrm{MFC}+\mathrm{FO}$ & $\begin{array}{c}\text { Enhance } \\
\text { Bio-electricity and } \\
\text { water recovery }\end{array}$ & $\begin{array}{l}0.5 \mathrm{M} \\
\mathrm{NaCl}\end{array}$ & $\begin{array}{l}\text { PES membrane } \\
\text { from Aquaporin }\end{array}$ & $\begin{array}{l}\text { Synthetic } \\
\text { wastewater }\end{array}$ & $\begin{array}{c}\text { Maximum power density of } \\
4.38 \mathrm{~W} / \mathrm{m}^{3} \text { and } 97 \% \text { organic } \\
\text { matters removal }\end{array}$ & {$[118]$} \\
\hline 4 & OMBR & l & $1 \mathrm{M} \mathrm{MgCl}_{2}$ & $\begin{array}{l}\text { CTA membrane } \\
\text { from HTI }\end{array}$ & $\begin{array}{l}\text { Synthetic } \\
\text { dyeing } \\
\text { wastewater }\end{array}$ & $99.4 \pm 0.1 \%$ COD removal & [9] \\
\hline 5 & MF-OMBR & $\begin{array}{l}\text { Remove silver } \\
\text { nanoparticles }\end{array}$ & $1 \mathrm{M} \mathrm{NaCl}$ & $\begin{array}{l}\text { TFC membrane } \\
\text { from HTI }\end{array}$ & $\begin{array}{l}\text { Simulated } \\
\text { wastewater }\end{array}$ & $\begin{array}{l}\text { More than 95\% Ag NPs } \\
\text { removal, } 98 \% \text { TOC removal, } \\
6.5 \mathrm{LMH}(\mathrm{s})\end{array}$ & [119] \\
\hline 6 & MF-OMBR & $\begin{array}{l}\text { Increase sludge } \\
\text { concentrations }\end{array}$ & $\begin{array}{l}0.5 \mathrm{M} \\
\mathrm{NaCl}\end{array}$ & $\begin{array}{l}\text { TFC membrane } \\
\text { from HTI }\end{array}$ & $\begin{array}{c}\text { Synthetic } \\
\text { wastewater }\end{array}$ & $\begin{array}{l}\text { Low salinity, high MLSS } \\
\text { concentration, 9.67 LMH }\end{array}$ & [107] \\
\hline 7 & $\mathrm{FO}+\mathrm{AB}$ & $\begin{array}{l}\text { Concentrated the } \\
\text { organics in } \\
\text { domestic } \\
\text { wastewater to } \\
10 \text {-fold }\end{array}$ & $\begin{array}{l}2.2 \mathrm{M} \\
\mathrm{MgCl}_{2}\end{array}$ & $\begin{array}{l}\text { TFC membrane } \\
\text { from HTI }\end{array}$ & $\begin{array}{c}\text { Domestic } \\
\text { wastewater }\end{array}$ & $\begin{array}{l}\text { Enhanced VFA production by } \\
7 \% \text { for secondary sludge and } \\
\text { by } 35 \% \text { for A-sludge }\end{array}$ & {$[120]$} \\
\hline 8 & $\begin{array}{l}\mathrm{UF}+\mathrm{FO}+ \\
\mathrm{MD}\end{array}$ & $\begin{array}{l}\text { Treated oily water } \\
\text { and utilization its } \\
\text { high salinity and } \\
\text { temperature }\end{array}$ & $\begin{array}{l}\text { Sanitary } \\
\text { sewage }\end{array}$ & $\begin{array}{c}\text { Ceramic membrane } \\
+ \text { HTI FO } \\
\text { membrane + MD }\end{array}$ & Oily water & $\begin{array}{l}96.4 \% \text { oil recovered by UF } \\
\text { and FO-MD utilization } \\
\text { membrane flux decline rate } \\
\text { of } 17.2 \% \text { and } 19.5 \% \text {. }\end{array}$ & [121] \\
\hline
\end{tabular}

\subsection{Process Economics}

During the operation of the FO process, the filtration process does not require external pressure, but the operating cost of the process cannot be ignored, especially the cost of the energy consumption of the DS recovery and regeneration.

Jasmina [122] employed three DS with equivalent permeate fluxes, $0.6 \mathrm{M} \mathrm{NaCl}$, blue dye mixture, and green dye mixture to process the textile wastewater. $\mathrm{NaCl}$-DS was recovered and regenerated by traditional RO. The diluted DS blue dye mixture and green dye mixture can be utilized as the raw materials in other stages of the dyeing process. The research was conducted the varieties analysis cost of the system based on $90 \mathrm{~m}^{3} / \mathrm{d}$ wastewater under three scenarios, including the cost of the FO and the RO membrane materials, which was purchased through amortizations calculations as an interest rate of $5.3 \%$ and the service life of the membrane was calculated as five years, the electricity cost of the FO and RO pump, and the DS replenishment cost. The total cost was calculated as $0.37 € / \mathrm{m}^{3}, 0.46 € / \mathrm{m}^{3}$, and $0.35 € / \mathrm{m}^{3}$. The results showed that although the cost of NaCl-RO scenario was the least, the system using dye mixture as DS produced 50\% less sewage discharged to the municipal sewage treatment plant than NaCl-DS. This part of the effluent can be used in the dye solution preparation process or utilized as washing water for flushing toilets and machines. Additionally, tap water is $0.47 € / \mathrm{m}^{3}$ currently, and with the aggravation of shortage of water resources, the price will very likely continue to increase in the future. From the perspective of the comprehensive utilization of resources and economic analysis, the FO system with blue dye mixture as DS was the most economic and proposed as the conclusion from the study.

Federico $[90,123]$ exploited a FO process to recover phosphorus, nitrogen, and other substances from human urine with $\mathrm{Mg}\left(\mathrm{NO}_{3}\right)_{2} \cdot 6 \mathrm{H}_{2} \mathrm{O}$ as DS. The urine was concentrated and reclaimed as $\mathrm{N}$ $\left(2.24 \mathrm{AUD} / \mathrm{kg}\right.$ ) with the recovery rate of $50 \%$, meanwhile the concentrated $\mathrm{PO}_{4}{ }^{3-}$ and the $\mathrm{RSD} \mathrm{Mg}^{2+}$ could be recovered as struvite. As a result, the recovery rate was up to $93 \%$ of $\mathrm{P}$ by adding $\mathrm{Mg}^{2+}$, which is $2.4 \mathrm{AUD} / \mathrm{kg}$ with the price. The operating cost and capital cost were analyzed, and the benchmark revenue products were fixed as urea and struvite, including the theoretical cost savings of reducing the load for downstream sewage treatment plants. In addition, economic analysis included the cycle return research based on the investment of different FO flux. 
In the calculation of capital cost, it was assumed that the processing capacity was as $10 \mathrm{~m}^{3} / \mathrm{d}$ of urine, the equipment utilization rate was 0.95 , the annual interest rate was $6 \%$, and the efficiency of the pump was $85 \%$. The operating cost of electricity was 0.29 KWHM USD under the assumption. The largest component of the operating cost was the replacement of the FO membrane material, which reached $\$ 1000 /$ element. The researchers studied the return benefits based on three scenarios of different FO membrane flux (4.2 LMH, 6.5 LMH, and $8 \mathrm{LMH}$ ) with 1 year of the plant construction time. The higher the flux, the shorter the economic income return period and the greater the return rate. However, the flux was 4.2 LMH, exclusive of the $\mathrm{N}$ and P saving recovery, the investment return was scarcely achieved. On the other hand, with consideration of the returns of $\mathrm{N}$ and $\mathrm{P}$ saving recovery, the return revenue could increase exponentially over time. Hence the return period is the shortest and the return revenue was the highest with the FO flux of $8 \mathrm{LMH}$.

Sergi [124] used the FO-RO-AnMBR process to desalinate seawater compared to the traditional seawater RO process in three scenarios: (A) open-loop system; (B) open-loop system, RO recovery at $45 \%$; (C) closed-loop system, $\mathrm{RO}$ was established by the osmotic pressure of the synthetic draw solution. These scenarios were analyzed under three FO recovery rates $(50 \%, 80 \%, 90 \%)$, and the economic benefits were considered. The flux with the solution-diffusion model was calculated. The pump efficiency was calculated as $85 \%$, the FO consumption was $0.3875 \mathrm{KWHM}^{-3}$. The study found that chemical cleaning accounted for the highest cost. With the recovery rates of $50 \%, 80 \%$, and $90 \%$ (the FO flux was 7.86 LMH, 5.9 LMH, 3.98 LMH) the total costs were $45 \%, 41 \%, 41 \%$, respectively. Meanwhile, the higher the recovery rate, the lower the energy consumption cost. The $90 \%$ recovery rate accounted for $14 \%$ of the energy consumption cost, which is much lower than the $50 \%$ recovery rate of $19 \%$ and $80 \%$ recovery rate of $17 \%$. The lowest total cost was $0.81 € / \mathrm{m}^{3}$ at $50 \%$ FO recovery rate, and 1.01 and $1.27 € / \mathrm{m}^{3}$ at $80 \%$ and $90 \%$ recovery rates, respectively.

The following proposals could be acquired from the research previously mentioned:

A. In terms of capital cost, the FO-RO system is usually higher than the traditional seawater $\mathrm{RO}$ process. This is mainly due to the higher input cost and replacement cost of the FO membrane material. However, in the subsequent operation energy consumption, the FO-RO system will show huge advantages, which could reduce the operating costs greatly $[125,126]$. For example, In C mode, at $50 \%$ recovery rate, the cost consumption was reduced by $30-40 \%$ compared to the traditional RO mode $[127,128]$ if the feed solution was concentrated to produce economically beneficial products or diluted DS could be directly utilized as the raw materials in other production processes, it greatly reduced the operating costs and even obtain higher economic benefits as mentioned in Sergi's study.

B. The flux of the FO membrane is still a significant limiting factor of the FO process. As referred in Federico's research, a small increase in the FO flux would greatly shorten the period of return on investment (without considering the saving $\mathrm{N}$, P conditions, 2.5 years of $6.5 \mathrm{LMH}, 5.5$ years of $8 \mathrm{LMH}$ ). Sergi's research also found that by increasing flux to $10 \mathrm{LMH}$, the FO-RO-AnMBR process would cut down the operating energy consumption, which greatly reduced the operating cost. In the long-term operation, the total cost could greatly be reduced, and it will represent powerful advantages compared with the traditional seawater desalination RO process.

\section{Fouling Mechanism and Cleaning Strategy}

A better understanding of the FO fouling mechanisms and fouling cleaning strategies will be beneficial for further application of FO.

The main driving force of FO due to its membrane permeation process is osmotic pressure, different from UF, NF, RO, and other membrane filtration processes which require higher external pressure as driving force, membrane fouling is relatively light and easy to clean.

However, membrane fouling remains a major drawback that cannot be ignored in FO systems. Various substances that pass through the membrane accumulate on the membrane surface and inside the membrane pores by physical adsorption bridging, positive and negative charge attraction, 
and adhesion. These substances include inorganic contaminant, organic substances, microorganisms, and their excretions in the FS and the DS.

Observation of the characteristics of pollution is a critical issue, which is of great significance for the pretreatment process of the FO treatment and the mitigation of pollution. It is still complicated to clarify the forming and evolution mechanism of membrane fouling. Although anti-contamination FO membrane materials are continuously improving, and the FO system operating conditions, cleaning component unit systems, and cleaning strategies are continually being optimized, membrane fouling is still unavoidable.

Membrane fouling can be classified as physical, chemical, and microbial contamination. Generally, the chemical properties of the FO membrane are characterized by surface chargeability, hydrophilicity, zeta potential, contact angle, etc. The physical morphology of the FO membrane fouling is characterized by scanning electron microscopy (SEM) and atomic force microscopy (AFM), three-dimensional fluorescence chromatography, and confocal laser scanning microscope (CLSM).

Moreover, the ultrasonic time domain reflectometry can be used to reflect the real-time dynamic change of the membrane fouling filter layer growth through the sensitive change of the ultrasonic signal, which also provides a guiding direction for the membrane cleaning operation process. Bio-contamination over nuclear magnetic resonance in membrane fouling can visualize the distribution of biofilms [129].

In the recent study of FO membrane pollution, Yan Sun [130] compared the dynamics of microbial populations and quantities in direct FO and OMBR system with the treatment of domestic sewage. It was observed that within 30 days of direct FO system, organic, inorganic, and biological pollution are more severe, so the water permeate flux declined drastically. However, as the operating time increased, the direct FO system fouling cake layer tended to be stable. Meanwhile, about 8 days running, the concentration of inorganic and bacteria quantities in the OMBR system was relatively stable. The cumulative concentration of organic matter was also lower than that of the direct FO system. This resulted in that OMBR water permeate flux was significantly higher than in the direct FO system. Yan Sun also revealed that after long-term operating, the FO system and OMBR had similar contaminant removal efficiencies; nevertheless, there were higher concentrations of polysaccharides, proteins, inorganic ions, and a large number of bacteria accumulated on the membrane surface of the FO system while this phenomenon was not obvious in the OMBR system. In the FO system, the fouling cake layer was much thicker than that in the OMBR system, however, the water permeate flux recovery of the FO system is much larger than that of the OMBR after hydraulic cleaning.

Tiffany [131] investigated a novel ultra-thin, FO hollow fiber membrane module to treat unconventional oil and gas fields in Texas. Compared the membranes fouling tendency in both FO and PRO modes at varied membrane cross flow velocities. The results demonstrated that the membrane foulant cake layer deposited faster in PRO mode than that in FO mode. In both modes, higher operating cross flow velocity was more likely to form membrane fouling cake layer. Finally, it was recommended that treating oilfield produced water employed FO process need to increase pretreatment step before the treatment unit. The pretreatment step aimed to remove the organic components and large particulate matter to increase the service life of the FO membrane module, delay the formation cycle of the fouling cake layer, and prolong the cleaning cycle [131].

Zhao Pin [132] studied the membrane fouling mechanism of proteins and fatty acids in the process of FO. The TFC membrane developed by Samsung of South Korea was used in the study. The membrane was constituted of a thin polyester nonwoven fabric, a polysulfone support layer, and a polyamide active layer. Bovine serum albumin (BSA) and octanoic acid (OA) synthetic wastewater were selected as typical pollutants of protein and fatty acid in municipal sewage secondary effluent. Results showed that the presence of $\mathrm{Ca}^{2+}$ promoted the formation of $\mathrm{BSA}-\mathrm{Ca}^{2+}$ complex, which aggravated the membrane fouling. With the ion concentration increased, the electrostatic repulsion was weakened, and the contamination of BSA was aggravated. The acidity and alkalinity of the solution also affected the degree of contamination of BSA through electrostatic interaction. At the isoelectric 
point of $\mathrm{BSA}, \mathrm{pH}=4.7$, pollution was the most serious. PRO mode membrane fouling was more severe than the FO mode. Under the alkaline condition, OA had the effect of surfactant, the water permeate flux of pollutant $\mathrm{OA}$ was relatively high, the degree of membrane fouling was mitigated, and the hydrophilicity of the membrane was enhanced. However, at $\mathrm{pH}=3.56$, the OA molecule tended to adhere to the surface of the membrane and form a gel layer which membrane aggravated the membrane fouling.

Fezeh [133] observed an interesting water flux pattern during FO with seawater as the DS and synthetic wastewater as the FS. The water flux was declined as the sinusoidal pattern. The water flux was spontaneously increased and decreased at regular time intervals. The phenomenon may be due to the buildup of the loose fouling layer peered off from the surface of the membrane with the cross flow shear rate. And a simple physical or hydraulic cleaning was able to restore the initial flux by up to $90 \%$. In the studies, it is indicated that increasing the cross-flow velocity at a specific time was able to significantly recover the water flux.

Recent studies on the FO process system fouling and cleaning strategies were shown in Table 6.

Table 6. Listed the main foulant in membrane fouling of the FO process system and the cleaning strategies in recently references.

\begin{tabular}{|c|c|c|c|c|c|}
\hline Author & Year & FS & Foulant & Cleaning Strategy & Ref. \\
\hline Yan Xiao Zhao & 2016 & $\begin{array}{l}\text { AgNPs } 1-10 \mathrm{mg} / \mathrm{L} \\
\text { BSA } 200 \mathrm{mg} / \mathrm{L}\end{array}$ & $\begin{array}{l}\text { Silver nanoparticles and } \\
\text { combination with } \\
\text { organism(BSA) }\end{array}$ & No mentioned & [134] \\
\hline Yan Sun & 2016 & $\begin{array}{l}\text { Municipal } \\
\text { wastewater }\end{array}$ & $\begin{array}{l}\text { Microbes, polysaccharides, } \\
\text { proteins, } \mathrm{Ca}^{2+}, \mathrm{Mg}^{2+}, \mathrm{Fe}^{2+}\end{array}$ & $\begin{array}{l}\text { Hydraulic and } \\
\text { chemical cleaning }\end{array}$ & [135] \\
\hline Zhao Pin & 2016 & $\begin{array}{c}\text { Simulated } \\
\text { wastewater with BSA } \\
\text { and OA }\end{array}$ & 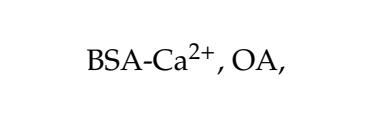 & No mentioned & [132] \\
\hline Youngbeom & 2017 & $\begin{array}{l}\text { Second effluent of } \\
\text { sewage with } \\
\text { Activated sludge }\end{array}$ & Microbes & $\begin{array}{l}\text { Physical cleaning } \\
\text { Air scouring }\end{array}$ & [8] \\
\hline Fezeh Lotfi & 2017 & Synthetic water & Polysaccharides, proteins & $\begin{array}{l}\text { A higher cross-flow } \\
\text { velocity shear }\end{array}$ & [133] \\
\hline Sung-Ju & 2018 & $\begin{array}{c}\text { Real secondary } \\
\text { wastewater effluent }\end{array}$ & $\begin{array}{l}\text { Hydrophilic aromatic } \\
\text { proteins }(\mathrm{MWs}=\mathrm{Da}), \\
\text { soluble microbial by } \\
\text { products }\end{array}$ & $\begin{array}{l}\text { Physical cleaning } \\
\text { with DI water }\end{array}$ & [136] \\
\hline Tiffany & 2019 & $\begin{array}{c}\text { Produced water from } \\
\text { oil and gas } \\
\text { development }\end{array}$ & $\begin{array}{l}\text { Organic constituents, large } \\
\text { particles }\end{array}$ & Hydraulic cleaning & [137] \\
\hline
\end{tabular}

Therefore, the driving force of the FO membrane relies on the osmotic pressure, a natural force. Therefore, the formed fouling cake layers generally have a weak binding force with the membrane, and most of the water permeate flux can be recovered a large proportion by simple physical and high-speed hydraulic washing. Specifically, the FS is oily wastewater, at present, there is little research on the preparation and modification of FO membranes for hydrophilic and also oleophobic. Furthermore, the commercial and prosperities stable products are scarce. FO with oily FS and produced water in oilfield through high-speed hydraulic flushing is only able to restore a low share of water permeate flux. Hence, chemical cleaning is considerably required. The advanced strategy of chemical cleaning remains to be further researched and developed.

In addition, the properties of the FO membrane-e.g., the structural properties of the FO membrane, the hydrophilicity of the material, the electronegativity, the physicochemical properties of the surface group, etc.-the physicochemical properties of the FS and the DS, the value of RSF, and during 
osmosis process, ICP, external CP (ECP), and operating time may also affect the formation period of the membrane fouling cake layer, the severity of membrane fouling.

The FO process was frequently applied to treat domestic sewage, seawater desalination, dyeing wastewater, dairy wastewater, concentrated beverages, and so on. The membrane fouling generally was recovered by conventional hydraulic cleaning or even a higher cross-flow velocity shear. Chemical cleaning was employed under the higher recovery rate of flux occasionally, but the wastewater with complex components-such as landfill leachate, coal chemical wastewater, and oilfield produced wastewater [138], etc.- -and the component polarity varied considerably, membrane fouling was formed more quickly and severely. After a period of water flushing, most membranes needed a chemical cleaning, which greatly damaged the mechanical strength and shorten the lifetime of the FO membrane, since the price of the FO membrane was relatively expensive compared to the RO membrane at present, the project operating cost increased substantially as a result.

\section{Conclusions}

The FO membrane has shown promising prospects in both drinking water purification and wastewater treatment technology, especially its excellent high rejection rate performance and relatively low membrane fouling characteristics. Hence it is likely to become a very important membrane technology in the future.

In the last 10 years, a large number of research papers on the focus above mentioned of the FO has been published $[139,140]$, and the number of papers in various issues has increased year by year, especially in the issues of the draw solution and the membrane material which is shown in Figure 3. The draw solution issues have grown from less than 10 articles in 2010 to a peak of more than 60 in 2016. The number decreased slightly from 2016 to 2019; and the number of articles about membrane materials increased from less than 10 in 2010 to over 50 in 2019, particularly from 2014 to 2015 grew rapidly, with the number multiplied from 20 to 40 , which was nearly doubled. With regard to membrane fouling, the total number of papers has grown sluggishly, from less than 10 to 30. Besides, in the papers on membrane fouling, there are few articles on the analysis of membrane fouling.

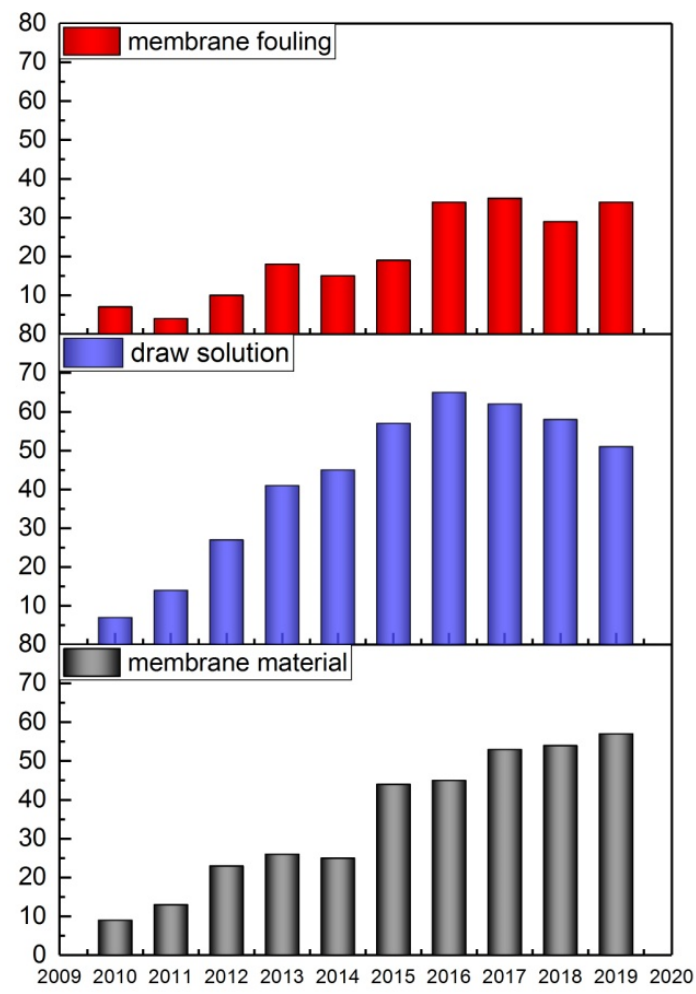

Figure 3. Number of papers in the three topics in the past 10 years. 
There are still several key technical issues that need to be addressed. The ideal membrane material, suitable draw solute and its recovery approach, the mechanism of special wastewater membrane fouling, and the cleaning strategies are still existing urgent barriers and they are still the researchers' focus in the future, improving the FO process in the following aspects: (a) high water flux, low RSF, high mechanical strength, low ICP film material modification and preparation; (b) special modification and preparation of properties or functional membrane materials; (c) development of new composite DS; (d) the membrane fouling principle and fouling cake layer formation mechanism; (e) the principle and solving methods of the accumulation of pollutants and salinity in the DS; (f) membrane fouling mitigation and membrane cleaning methods and strategies. A lot of in-depth experiments and research are still needed in these areas.

Specifically, among the properties of the FO membrane material, it is the particular focus as follows, the preparation of the FO membranes with excellent performance properties, the perfect draw solutes preparation or choice. It is strongly recommended that the research on strengthening other performance properties of membrane materials with superior performance in specific properties systematically and comprehensively. More attention needs to be paid to preparation uniformity, and the preparation of the draw solutes applied to the appropriate field.

In addition, the review highlights some of the new technologies mentioned that can be used to solve some of the above problems. However, the engineering of the forward osmosis process application is relatively scarce as most of the FO research is still in the laboratory scale, and progress in practical applications still requires further proof of the pilot. Finally, in order to provide theoretical support for the preparation and cleaning strategy of membrane materials, more in-depth and basic research on membrane fouling mechanism is needed, which still has a large gap in the current research results. These concepts mentioned in this review will provide a better understanding for further promoting the utilization of FO technology and its new applications for freshwater resources recovery and wastewater treatment development.

Author Contributions: For the study, the conceptualization was proposed by L.L. and W.S., the research methodology was conducted by L.L. and S.Y., the formal analysis, the investigation were completed by L.L., the data management work and writing-original draft were carried out by L.L., the writing-review and editing were accomplished by W.S. and S.Y., and the funding was acquired by W.S. and S.Y. All authors have read and agreed to the published version of the manuscript.

Funding: Shuili Yu is grateful for the financial support provided by the National Natural Science Foundation of China (No. 51578390, 51808257, 51708130); Wenxin Shi is grateful for the financial support provided by the National Natural Science Foundation of China (No. 51978098) and the Major Science and Technology Program for Water Pollution Control and Treatment (No. 2017ZX07502003).

Conflicts of Interest: The authors declare no conflicts of interest.

\section{Abbreviations}

$\begin{array}{ll}\text { FO } & \text { forward osmosis } \\ \text { RSF } & \text { reverse solute flux } \\ \text { CP } & \text { concentration polarization } \\ \text { ICP } & \text { internal concentration polarization } \\ \text { ECP } & \text { external concentration polarization } \\ \text { MF } & \text { microfiltration } \\ \text { UF } & \text { ultrafiltration } \\ \text { NF } & \text { nanofiltration } \\ \text { RO } & \text { reverse osmosis } \\ \text { FS } & \text { feed solution } \\ \text { DS } & \text { draw solution } \\ \text { PRO } & \text { pressure retarded osmosis } \\ \text { RSD } & \text { reverse solute diffusion } \\ \text { MD } & \text { membrane distillation } \\ \text { TFC } & \text { thin-film composite }\end{array}$




$\begin{array}{ll}\text { CTA } & \text { cellulose tri-acetate } \\ \text { AQP } & \text { aquaporin } \\ \text { BSA } & \text { bovine serum albumin } \\ \text { LMH } & \mathrm{L} /\left(\mathrm{m}^{2} \cdot \mathrm{h}\right) \\ \text { KWHM } & \mathrm{kWh} \cdot \mathrm{m}^{-3}\end{array}$

\section{References}

1. Linares, R.V.; Li, Z.; Sarp, S.; Bucs, S.S.; Amy, G.; Vrouwenvelder, J.S. Forward osmosis niches in seawater desalination and wastewater reuse. Water Res. 2014, 66, 122-139. [CrossRef]

2. Korenak, J.; Basu, S.; Balakrishnan, M.; Helix-Nielsen, C.; Petrinic, I. Forward Osmosis in Wastewater Treatment Processes. Acta Chim. Slov. 2017, 64, 83-94. [CrossRef] [PubMed]

3. Hey, T.; Bajraktari, N.; Davidsson, A.; Vogel, J.; Madsen, H.T.; Helix-Nielsen, C.; Jansen, J.L.C.; Jonsson, K. Evaluation of direct membrane filtration and direct forward osmosis as concepts for compact and energy-positive municipal wastewater treatment. Environ. Technol. 2018, 39, 264-276. [CrossRef] [PubMed]

4. Shaffer, D.L.; Werber, J.R.; Jaramillo, H.; Lin, S.; Elimelech, M. Forward osmosis: Where are we now? Desalination 2015, 356, 271-284. [CrossRef]

5. Pramanik, B.K.; Shu, L.; Jegatheesan, V. A review of the management and treatment of brine solutions. Environ. Sci. Water Res. Technol. 2017, 3, 625-658. [CrossRef]

6. Liu, C.; Lei, X.; Wang, L.; Jia, J.; Liang, X.; Zhao, X.; Zhu, H. Investigation on the removal performances of heavy metal ions with the layer-by-layer assembled forward osmosis membranes. Chem. Eng. J. 2017, 327, 60-70. [CrossRef]

7. Wang, X.; Zhang, J.; Chang, V.W.C.; She, Q.; Tang, C.Y. Removal of cytostatic drugs from wastewater by an anaerobic osmotic membrane bioreactor. Chem. Eng. J. 2018, 339, 153-161. [CrossRef]

8. Yu, Y.; Lee, S.; Maeng, S.K. Forward osmosis membrane fouling and cleaning for wastewater reuse. J. Water Reuse Desalin. 2017, 7, 111-120. [CrossRef]

9. Li, F.; Xia, Q.; Gao, Y.; Cheng, Q.; Ding, L.; Yang, B.; Tian, Q.; Ma, C.; Sand, W.; Liu, Y. Anaerobic biodegradation and decolorization of a refractory acid dye by a forward osmosis membrane bioreactor. Environ. Sci. Water Res. Technol. 2018, 4, 272-280. [CrossRef]

10. Logan, B.E.; Elimelech, M. Membrane-based processes for sustainable power generation using water. Nature 2012, 488, 313-319. [CrossRef]

11. Qasim, M.; Mohammed, F.; Aidan, A.; Darwish, N.A. Forward osmosis desalination using ferric sulfate draw solute. Desalination 2017, 423, 12-20. [CrossRef]

12. Li, S.; Kim, Y.; Chekli, L.; Phuntsho, S.; Shon, H.K.; Leiknes, T.; Ghaffour, N. Impact of reverse nutrient diffusion on membrane biofouling in fertilizer-drawn forward osmosis. J. Membr. Sci. 2017, 539, 108-115. [CrossRef]

13. Wang, J.; Pathak, N.; Chekli, L.; Phuntsho, S.; Kim, Y.; Li, D.; Shon, H.K. Performance of a Novel Fertilizer-Drawn Forward Osmosis Aerobic Membrane Bioreactor (FDFO-MBR): Mitigating Salinity Build-Up by Integrating Microfiltration. Water 2017, 9, 21. [CrossRef]

14. Chun, Y.; Mulcahy, D.; Zou, L.; Kim, I.S. A Short Review of Membrane Fouling in Forward Osmosis Processes. Membranes 2017, 7, 30. [CrossRef]

15. Khorshidi, B.; Bhinder, A.; Thundat, T.; Pernitsky, D.; Sadrzadeh, M. Developing high throughput thin film composite polyamide membranes for forward osmosis treatment of SAGD produced water. J. Membr. Sci. 2016, 511, 29-39. [CrossRef]

16. McCutcheon, J.R.; Elimelech, M. Influence of concentrative and dilutive internal concentration polarization on flux behavior in forward osmosis. J. Membr. Sci. 2006, 284, 237-247. [CrossRef]

17. Akther, N.; Sodiq, A.; Giwa, A.; Daer, S.; Arafat, H.A.; Hasan, S.W. Recent advancements in forward osmosis desalination: A review. Chem. Eng. J. 2015, 281, 502-522. [CrossRef]

18. Tang, C.; Wang, Z.; Petrinic, I.; Fane, A.G.; Helix-Nielsen, C. Biomimetic aquaporin membranes coming of age. Desalination 2015, 368, 89-105. [CrossRef]

19. Zhang, H.; Jiang, W.; Cui, H. Performance of anaerobic forward osmosis membrane bioreactor coupled with microbial electrolysis cell (AnOMEBR) for energy recovery and membrane fouling alleviation. Chem. Eng. J. 2017, 321, 375-383. [CrossRef] 
20. McCutcheon, J.R.; Elimelech, M. Influence of membrane support layer hydrophobicity on water flux in osmotically driven membrane processes. J. Membr. Sci. 2008, 318, 458-466. [CrossRef]

21. Klaysom, C.; Cath, T.Y.; Depuydt, T.; Vankelecom, I.F.J. Forward and pressure retarded osmosis: Potential solutions for global challenges in energy and water supply. Chem. Soc. Rev. 2013, 42, 6959-6989. [CrossRef] [PubMed]

22. Bell, E.A.; Poynor, T.E.; Newhart, K.B.; Regnery, J.; Coday, B.D.; Cath, T.Y. Produced water treatment using forward osmosis membranes: Evaluation of extended-time performance and fouling. J. Membr. Sci. 2017, 525, 77-88. [CrossRef]

23. Chen, G.; Wang, Z.; Nghiem, L.D.; Li, X.; Xie, M.; Zhao, B.; Zhang, M.; Song, J.; He, T. Treatment of shale gas drilling flowback fluids (SGDFs) by forward osmosis: Membrane fouling and mitigation. Desalination 2015, 366, 113-120. [CrossRef]

24. Coday, B.D.; Almaraz, N.; Cath, T.Y. Forward osmosis desalination of oil and gas wastewater: Impacts of membrane selection and operating conditions on process performance. J. Membr. Sci. 2015, 488, 40-55. [CrossRef]

25. Duong, P.H.H.; Chung, T.-S. Application of thin film composite membranes with forward osmosis technology for the separation of emulsified oil-water. J. Membr. Sci. 2014, 452, 117-126. [CrossRef]

26. You, S.; Tang, C.; Yu, C.; Wang, X.; Zhang, J.; Han, J.; Gan, Y.; Ren, N. Forward Osmosis with a Novel Thin-Film Inorganic Membrane. Environ. Sci. Technol. 2013, 47, 8733-8742. [CrossRef]

27. Wang, K.Y.; Ong, R.C.; Chung, T.-S. Double-Skinned Forward Osmosis Membranes for Reducing Internal Concentration Polarization within the Porous Sublayer. Ind. Eng. Chem. Res. 2010, 49, 4824-4831. [CrossRef]

28. Qin, D.; Liu, Z.; Sun, D.D.; Song, X.; Bai, H. A new nanocomposite forward osmosis membrane custom-designed for treating shale gas wastewater. Sci. Rep. 2015, 5. [CrossRef]

29. Choi, H.-g.; Son, M.; Choi, H. Integrating seawater desalination and wastewater reclamation forward osmosis process using thin-film composite mixed matrix membrane with functionalized carbon nanotube blended polyethersulfone support layer. Chemosphere 2017, 185, 1181-1188. [CrossRef]

30. Pan, S.F.; Dong, Y.C.; Zheng, Y.M.; Zhong, L.B.; Yuan, Z.H. Self-sustained hydrophilic nanofiber thin film composite forward osmosis membranes: Preparation, characterization and application for simulated antibiotic wastewater treatment. J. Membr. Sci. 2017, 523, 205-215. [CrossRef]

31. Li, Z.; Linares, R.V.; Bucs, S.; Fortunato, L.; Helix-Nielsen, C.; Vrouwenvelder, J.S.; Ghaffour, N.; Leiknes, T.; Amy, G. Aquaporin based biomimetic membrane in forward osmosis: Chemical cleaning resistance and practical operation. Desalination 2017, 420, 208-215. [CrossRef]

32. Tang, C.Y.; Zhao, Y.; Wang, R.; Helix-Nielsen, C.; Fane, A.G. Desalination by biomimetic aquaporin membranes: Review of status and prospects. Desalination 2013, 308, 34-40. [CrossRef]

33. Zhao, X.; Liu, C. Efficient removal of heavy metal ions based on the optimized dissolution-diffusion-flow forward osmosis process. Chem. Eng. J. 2018, 334, 1128-1134. [CrossRef]

34. Qin, D.; Liu, Z.; Liu, Z.; Bai, H.; Sun, D.D. Superior Antifouling Capability of Hydrogel Forward Osmosis Membrane for Treating Wastewaters with High Concentration of Organic Foulants. Environ. Sci. Technol. 2018, 52, 1421-1428. [CrossRef]

35. You, S.; Lu, J.; Tang, C.Y.; Wang, X. Rejection of heavy metals in acidic wastewater by a novel thin-film inorganic forward osmosis membrane. Chem. Eng. J. 2017, 320, 532-538. [CrossRef]

36. Ma, D.; Han, G.; Peh, S.B.; Chen, S.B. Water-Stable Metal-Organic Framework UiO-66 for Performance Enhancement of Forward Osmosis Membranes. Ind. Eng. Chem. Res. 2017, 56, 12773-12782. [CrossRef]

37. Cruz-Tato, P.; Ortiz-Quiles, E.O.; Vega-Figueroa, K.; Santiago-Martoral, L.; Flynn, M.; Diaz-Vazquez, L.M.; Nicolau, E. Metalized Nanocellulose Composites as a Feasible Material for Membrane Supports: Design and Applications for Water Treatment. Environ. Sci. Technol. 2017, 51, 4585-4595. [CrossRef]

38. Qi, S.; Qiu, C.Q.; Zhao, Y.; Tang, C.Y. Double-skinned forward osmosis membranes based on layer-by-layer assembly-FO performance and fouling behavior. J. Membr. Sci. 2012, 405, 20-29. [CrossRef]

39. Ong, C.S.; Al-anzi, B.; Lau, W.J.; Goh, P.S.; Lai, G.S.; Ismail, A.F.; Ong, Y.S. Anti-Fouling Double-Skinned Forward Osmosis Membrane with Zwitterionic Brush for Oily Wastewater Treatment. Sci. Rep. 2017, 7. [CrossRef]

40. Bao, X.; Wu, Q.; Shi, W.; Wang, W.; Yu, H.; Zhu, Z.; Zhang, X.; Zhang, Z.; Zhang, R.; Cui, F. Polyamidoamine dendrimer grafted forward osmosis membrane with superior ammonia selectivity and robust antifouling capacity for domestic wastewater concentration. Water Res. 2019, 153, 1-10. [CrossRef] 
41. Bao, X.; Wu, Q.; Shi, W.; Wang, W.; Zhu, Z.; Zhang, Z.; Zhang, R.; Zhang, X.; Zhang, B.; Guo, Y.; et al. Insights into simultaneous ammonia-selective and anti-fouling mechanism over forward osmosis membrane for resource recovery from domestic wastewater. J. Membr. Sci. 2019, 573, 135-144. [CrossRef]

42. Xu, W.; Chen, Q.; Ge, Q. Recent advances in forward osmosis (FO) membrane: Chemical modifications on membranes for FO processes. Desalination 2017, 419, 101-116. [CrossRef]

43. Kang, G.-D.; Cao, Y.-M. Application and modification of poly (vinylidene fluoride) (PVDF) membranes-A review. J. Membr. Sci. 2014, 463, 145-165. [CrossRef]

44. Emadzadeh, D.; Ghanbari, M.; Lau, W.J.; Rahbari-Sisakht, M.; Rana, D.; Matsuura, T.; Kruczek, B.; Ismail, A.F. Surface modification of thin film composite membrane by nanoporous titanate nanoparticles for improving combined organic and inorganic antifouling properties. Mater. Sci. Eng. C Mater. Biol. Appl. 2017, 75, 463-470. [CrossRef] [PubMed]

45. Salehi, T.M.; Peyravi, M.; Jahanshahi, M.; Lau, W.-J.; Rad, A.S. Impacts of zeolite nanoparticles on substrate properties of thin film nanocomposite membranes for engineered osmosis. J. Nanoparticle Res. 2018, 20. [CrossRef]

46. Choi, B.G.; Zhan, M.; Shin, K.; Lee, S.; Hong, S. Pilot-scale evaluation of FO-RO osmotic dilution process for treating wastewater from coal-fired power plant integrated with seawater desalination. J. Membr. Sci. 2017, 540, 78-87. [CrossRef]

47. Peyravi, M.; Jahanshahi, M.; Rahimpour, A.; Javadi, A.; Hajavi, S. Novel thin film nanocomposite membranes incorporated with functionalized $\mathrm{TiO} 2$ nanoparticles for organic solvent nanofiltration. Chem. Eng. J. 2014, 241, 155-166. [CrossRef]

48. Liu, X.; Ong, S.L.; How Yong, N. Fabrication of mesh-embedded double-skinned substrate membrane and enhancement of its surface hydrophilicity to improve anti-fouling performance of resultant thin-film composite forward osmosis membrane. J. Membr. Sci. 2016, 511, 40-53. [CrossRef]

49. Shen, L.; Wang, Y. Efficient surface modification of thin-film composite membranes with self-catalyzed tris (2-aminoethyl)amine for forward osmosis separation. Chem. Eng. Sci. 2018, 178, 82-92. [CrossRef]

50. Singh, N.; Petrinic, I.; Helix-Nielsen, C.; Basu, S.; Balakrishnan, M. Concentrating molasses distillery wastewater using biomimetic forward osmosis (FO) membranes. Water Res. 2018, 130, 271-280. [CrossRef]

51. Kim, H.I.; Kim, S.S. Plasma treatment of polypropylene and polysulfone supports for thin film composite reverse osmosis membrane. J. Membr. Sci. 2006, 286, 193-201. [CrossRef]

52. Ghosh, A.K.; Hoek, E.M.V. Impacts of support membrane structure and chemistry on polyamide-polysulfone interfacial composite membranes. J. Membr. Sci. 2009, 336, 140-148. [CrossRef]

53. Vrijenhoek, E.M.; Hong, S.; Elimelech, M. Influence of membrane surface properties on initial rate of colloidal fouling of reverse osmosis and nanofiltration membranes. J. Membr. Sci. 2001, 188, 115-128. [CrossRef]

54. Ramon, G.Z.; Hoek, E.M.V. Transport through composite membranes, part 2: Impacts of roughness on permeability and fouling. J. Membr. Sci. 2013, 425, 141-148. [CrossRef]

55. Thompson, N.A.; Forward, P.G.N. Osmosis Desalination: A Commercial Reality. In Proceedings of the IDA World Congr.-Perth Conv. Exhib. Cent. (PCEC), Perth, Western Australia, 4-9 September 2011; p. 16.

56. Hutchings, N.R.; Appleton, E.W.; McGinnis, R.A. Making high quality frac water out of oilfield waste. In Proceedings of the SPE Annual Technical Conference and Exhibition, Florence, Italy, 20-22 September 2010; pp. 4991-5000.

57. Oasyswater.com. Available online: http://oasyswater.com (accessed on 15 November 2018).

58. Trevisystems.com. Available online: https://www.trevisystems.com (accessed on 14 November 2018).

59. Zeng, L.-M.; Du, M.-Y.; Wang, X.-L. A Thermodynamical Approach for Evaluating Energy Consumption of the Forward Osmosis Process Using Various Draw Solutes. Water 2017, 9, 189. [CrossRef]

60. Zhao, P.; Gao, B.; Yue, Q.; Kong, J.; Shon, H.K.; Liu, P.; Gao, Y. Explore the forward osmosis performance using hydrolyzed polyacrylamide as draw solute for dye wastewater reclamation in the long-term process. Chem. Eng. J. 2015, 273, 316-324. [CrossRef]

61. Jiang, Y.; Liang, J.; Liu, Y. Application of forward osmosis membrane technology for oil sands process-affected water desalination. Water Sci. Technol. 2016, 73, 1809-1816. [CrossRef]

62. Kravath, D.K.R.E.; Davis, J.A. Desalination of sea water by direct osmosis. Desalination 1975, 16, $151-155$. [CrossRef] 
63. Phuntsho, S.; Shon, H.K.; Hong, S.; Lee, S.; Vigneswaran, S. A novel low energy fertilizer driven forward osmosis desalination for direct fertigation: Evaluating the performance of fertilizer draw solutions. J. Membr. Sci. 2011, 375, 172-181. [CrossRef]

64. Ge, Q.; Han, G.; Chung, T.-S. Effective As (III) Removal by A Multi-Charged Hydroacid Complex Draw Solute Facilitated Forward Osmosis-Membrane Distillation (FO-MD) Processes. Environ. Sci. Technol. 2016, 50, 2363-2370. [CrossRef]

65. Mishra, T.; Ramola, S.; Shankhwar, A.K.; Srivastava, R.K. Use of synthesized hydrophilic magnetic nanoparticles (HMNPs) in forward osmosis for water reuse. Water Sci. Technol. Water Supply 2016, 16, 229-236. [CrossRef]

66. Chi, X.Y.; Zhang, P.Y.; Guo, X.J.; Xu, Z.L. Interforce initiated by magnetic nanoparticles for reducing internal concentration polarization in CTA forward osmosis membrane. J. Appl. Polym. Sci. 2017, 134, 10. [CrossRef]

67. Li, D.; Zhang, X.; Yao, J.; Simon, G.P.; Wang, H. Stimuli-responsive polymer hydrogels as a new class of draw agent for forward osmosis desalination. Chem. Commun. 2011, 47, 1710-1712. [CrossRef] [PubMed]

68. Cai, Y.; Shen, W.; Loo, S.L.; Krantz, W.B.; Wang, R.; Fane, A.G.; Hu, X. Towards temperature driven forward osmosis desalination using Semi-IPN hydrogels as reversible draw agents. Water Res. 2013, 47, 3773-3781. [CrossRef] [PubMed]

69. Lutchmiah, K.; Verliefde, A.R.D.; Roest, K.; Rietveld, L.C.; Cornelissen, E.R. Forward osmosis for application in wastewater treatment: A review. Water Res. 2014, 58, 179-197. [CrossRef] [PubMed]

70. Zhang, H.M.; Li, J.J.; Cui, H.T.; Li, H.J.; Yang, F.L. Forward osmosis using electric-responsive polymer hydrogels as draw agents: Influence of freezing-thawing cycles, voltage, feed solutions on process performance. Chem. Eng. J. 2015, 259, 814-819. [CrossRef]

71. Boo, C.; Khalil, Y.F.; Elimelech, M. Performance evaluation of trimethylamine-carbon dioxide thermolytic draw solution for engineered osmosis. J. Membr. Sci. 2015, 473, 302-309. [CrossRef]

72. Zhao, P.; Gao, B.; Xu, S.; Kong, J.; Ma, D.; Shon, H.K.; Yue, Q.; Liu, P. Polyelectrolyte-promoted forward osmosis process for dye wastewater treatment-Exploring the feasibility of using polyacrylamide as draw solute. Chem. Eng. J. 2015, 264, 32-38. [CrossRef]

73. Huang, J.; Long, Q.; Xiong, S.; Shen, L.; Wang, Y. Application of poly (4-styrenesulfonic acid-co-maleic acid) sodium salt as novel draw solute in forward osmosis for dye-containing wastewater treatment. Desalination 2017, 421, 40-46. [CrossRef]

74. Kim, J.E.; Phuntsho, S.; Chekli, L.; Hong, S.; Ghaffour, N.; Leiknes, T.; Choi, J.Y.; Shon, H.K. Environmental and economic impacts of fertilizer drawn forward osmosis and nanofiltration hybrid system. Desalination 2017, 416, 76-85. [CrossRef]

75. Yang, Y.; Chen, M.; Zou, S.; Yang, X.; Long, T.E.; He, Z. Efficient recovery of polyelectrolyte draw solutes in forward osmosis towards sustainable water treatment. Desalination 2017, 422, 134-141. [CrossRef]

76. Chen, Q.; Xu, W.; Ge, Q. Novel Multicharge Hydroacid Complexes That Effectively Remove Heavy Metal Ions from Water in Forward Osmosis Processes. Environ. Sci. Technol. 2018, 52, 4464-4471. [CrossRef] [PubMed]

77. Park, J.; Joo, H.; Noh, M.; Namkoong, Y.; Lee, S.; Jung, K.H.; Ahn, H.R.; Kim, S.; Lee, J.-C.; Yoon, J.H.; et al. Systematic structure control of ammonium iodide salts as feasible UCST-type forward osmosis draw solutes for the treatment of wastewater. J. Mater. Chem. A 2018, 6, 1255-1265. [CrossRef]

78. Wang, Z.X.; Wu, S.M.; He, Z. Production of electricity and water in an osmotic microbial fuel cell by using EDTA-Na-2 as a recoverable draw solute. Sci. Total Environ. 2019, 677, 382-389. [CrossRef]

79. Adnan, M.; Khan, S.J.; Manzoor, K.; Hankins, N.P. Performance evaluation of fertilizer draw solutions for forward osmosis membrane bioreactor treating domestic wastewater. Process Saf. Environ. Prot. 2019, 127, 133-140. [CrossRef]

80. Kim, D.I.; Gwak, G.; Zhan, M.; Hong, S. Sustainable dewatering of grapefruit juice through forward osmosis: Improving membrane performance, fouling control, and product quality. J. Membr. Sci. 2019, 578, 53-60. [CrossRef]

81. Gimun Gwak, D.I.K.; Kim, J. An integrated system for $\mathrm{CO}_{2}$ capture and water treatment by forward osmosis driven by an amine-based draw solution. J. Membr. Sci. 2019, 581, 9-17. [CrossRef]

82. Mattia Giagnorio, F.R.; Tiraferri, A. Desalination of brackish groundwater and reuse of wastewater by forward osmosis coupled with nanofiltration for draw solution recovery. Water Res. 2019, 153, 134-143. [CrossRef] 
83. Zeng, J.; Cui, S.; Wang, Q.; Chen, R. Multi-layer temperature-responsive hydrogel for forward-osmosis desalination with high permeable flux and fast water release. Desalination 2019, 459, 105-113. [CrossRef]

84. Lambrechts, R.; Sheldon, M.S. Performance and energy consumption evaluation of a fertiliser drawn forward osmosis (FDFO) system for water recovery from brackish water. Desalination 2019, 456, 64-73. [CrossRef]

85. Xu, L.; Zhang, L.; Du, L.; Zhang, S. Electro-catalytic oxidation in treating C.I. Acid Red 73 wastewater coupled with nanofiltration and energy consumption analysis. J. Membr. Sci. 2014, 452, 1-10. [CrossRef]

86. Lu, Y.; Qin, M.; Yuan, H.; Abu-Reesh, I.M.; He, Z. When Bioelectrochemical Systems Meet Forward Osmosis: Accomplishing Wastewater Treatment and Reuse through Synergy. Water 2015, 7, 38-50. [CrossRef]

87. Pal, P.; Chakrabortty, S.; Nayak, J.; Senapati, S. A flux-enhancing forward osmosis-nanofiltration integrated treatment system for the tannery wastewater reclamation. Environ. Sci. Pollut. Res. 2017, 24, 15768-15780. [CrossRef] [PubMed]

88. Xu, S.; Lin, P.; An, X.; Hu, Y.; Wang, Z.; Zhong, L.; Niu, Q. High-Performance Forward Osmosis Membranes Used for Treating High-Salinity Oil-Bearing Wastewater. Ind. Eng. Chem. Res. 2017, 56, 12385-12394. [CrossRef]

89. Zhu, S.; Li, M.; El-Din, M.G. Forward osmosis as an approach to manage oil sands tailings water and on-site basal depressurization water. J. Hazard. Mater. 2017, 327, 18-27. [CrossRef] [PubMed]

90. Volpin, F.; Chekli, L.; Phuntsho, S.; Cho, J.; Ghaffour, N.; Vrouwenvelder, J.S.; Kyong Shon, H. Simultaneous phosphorous and nitrogen recovery from source-separated urine: A novel application for fertiliser drawn forward osmosis. Chemosphere 2018, 203, 482-489. [CrossRef] [PubMed]

91. Gwak, G.; Kim, D.I.; Hong, S. New industrial application of forward osmosis (FO): Precious metal recovery from printed circuit board (PCB) plant wastewater. J. Membr. Sci. 2018, 552, 234-242. [CrossRef]

92. Chanukya, B.S.; Rastogi, N.K. Ultrasound assisted forward osmosis concentration of fruit juice and natural colorant. Ultrason. Sonochem. 2017, 34, 426-435. [CrossRef]

93. Mondal, D.; Nataraj, S.K.; Reddy, A.V.R.; Ghara, K.K.; Maiti, P.; Upadhyay, S.C.; Ghosh, P.K. Four-fold concentration of sucrose in sugarcane juice through energy efficient forward osmosis using sea bittern as draw solution. RSC Adv. 2015, 5, 17872-17878. [CrossRef]

94. Gawande, N.; Mungray, A.A. Superabsorbent polymer (SAP) hydrogels for protein enrichment. Sep. Purif. Technol. 2015, 150, 86-94. [CrossRef]

95. Liu, X.; Wu, J.; Liu, C.; Wang, J. Removal of cobalt ions from aqueous solution by forward osmosis. Sep. Purif. Technol. 2017, 177, 8-20. [CrossRef]

96. Chen, G.E.; Sun, W.; Wu, Q.; Kong, Y.; Xu, Z.; Xu, S.; Zheng, X. Effect of cellulose triacetate membrane thickness on forward-osmosis performance and application for spent electroless nickel plating baths. J. Appl. Polym. Sci. 2017, 134. [CrossRef]

97. Chekli, L.; Kim, Y.; Phuntsho, S.; Li, S.; Ghaffour, N.; Leiknes, T.; Shon, H.K. Evaluation of fertilizer-drawn forward osmosis for sustainable agriculture and water reuse in arid regions. J. Environ. Manag. 2017, 187, 137-145. [CrossRef] [PubMed]

98. Kedwell, K.C.; Quist-Jensen, C.A.; Giannakakis, G.; Christensen, M.L. Forward osmosis with high-performing TFC membranes for concentration of digester centrate prior to phosphorus recovery. Sep. Purif. Technol. 2018, 197, 449-456. [CrossRef]

99. Ansari, A.J.; Hai, F.I.; Price, W.E.; Drewes, J.E.; Nghiem, L.D. Forward osmosis as a platform for resource recovery from municipal wastewater-A critical assessment of the literature. J. Membr. Sci. 2017, 529, 195-206. [CrossRef]

100. Zhou, Y.; Huang, M.; Deng, Q.; Cai, T. Combination and performance of forward osmosis and membrane distillation (FO-MD) for treatment of high salinity landfill leachate. Desalination 2017, 420, 99-105. [CrossRef]

101. Song, H.; Xie, F.; Chen, W.; Liu, J. FO/MD hybrid system for real dairy wastewater recycling. Environ. Technol. 2017, 39, 2411-2421. [CrossRef]

102. Salih, H.H.; Dastgheib, S.A. Treatment of a hypersaline brine, extracted from a potential $\mathrm{CO}_{2}$ sequestration site, and an industrial wastewater by membrane distillation and forward osmosis. Chem. Eng. J. 2017, 325, 415-423. [CrossRef]

103. Rezakazemi, M.; Khajeh, A.; Mesbah, M. Membrane filtration of wastewater from gas and oil production. Environ. Chem. Lett. 2018, 16, 367-388. [CrossRef]

104. Zou, S.; He, Z. Electrodialysis recovery of reverse-fluxed fertilizer draw solute during forward osmosis water treatment. Chem. Eng. J. 2017, 330, 550-558. [CrossRef] 
105. Zhang, X.H.; Li, Q.G.; Wang, J.; Li, J.; Zhao, C.W.; Hou, D.Y. Effects of feed solution pH and draw solution concentration on the performance of phenolic compounds removal in forward osmosis process. J. Environ. Chem. Eng. 2017, 5, 2508-2514. [CrossRef]

106. Qin, M.; Hynes, E.A.; Abu-Reesh, I.M.; He, Z. Ammonium removal from synthetic wastewater promoted by current generation and water flux in an osmotic microbial fuel cell. J. Clean. Prod. 2017, 149, 856-862. [CrossRef]

107. Zhu, W.; Wang, X.; She, Q.; Li, X.; Ren, Y. Osmotic membrane bioreactors assisted with microfiltration membrane for salinity control (MF-OMBR) operating at high sludge concentrations: Performance and implications. Chem. Eng. J. 2018, 337, 576-583. [CrossRef]

108. Al-Mamun, A.; Baawain, M.S.; Egger, F.; Al-Muhtaseb, A.a.H.; Ng, H.Y. Optimization of a baffled-reactor microbial fuel cell using autotrophic denitrifying bio-cathode for removing nitrogen and recovering electrical energy. Biochem. Eng. J. 2017, 120, 93-102. [CrossRef]

109. Al-Mamun, A.; Baawain, M.S. Accumulation of intermediate denitrifying compounds inhibiting biological denitrification on cathode in Microbial Fuel Cell. J. Environ. Health Sci. Eng. 2015, 13. [CrossRef] [PubMed]

110. Al-Marnun, A.; Baawain, M.S.; Dhar, B.R.; Kim, I.S. Improved recovery of bioenergy and osmotic water in an osmotic microbial fuel cell using micro-diffuser assisted marine aerobic biofilm on cathode. Biochem. Eng. J. 2017, 128, 235-242. [CrossRef]

111. Besha, A.T.; Gebreyohannes, A.Y.; Tufa, R.A.; Bekele, D.N.; Curcio, E.; Giorno, L. Removal of emerging micropollutants by activated sludge process and membrane bioreactors and the effects of micropollutants on membrane fouling: A review. J. Environ. Chem. Eng. 2017, 5. [CrossRef]

112. Zhou, L.; Zhuang, W.; Wang, X.; Yu, K.; Yang, S.; Xia, S. Potential effects of loading nano zero valent iron discharged on membrane fouling in an anoxic/oxic membrane bioreactor. Water Res. 2017, 111, 140-146. [CrossRef]

113. Tadkaew, N.; Hai, F.I.; McDonald, J.A.; Khan, S.J.; Nghiem, L.D. Removal of trace organics by MBR treatment: The role of molecular properties. Water Res. 2011, 45, 2439-2451. [CrossRef]

114. Chon, K.; Sarp, S.; Lee, S.; Lee, J.-H.; Lopez-Ramirez, J.A.; Cho, J. Evaluation of a membrane bioreactor and nanofiltration for municipal wastewater reclamation: Trace contaminant control and fouling mitigation. Desalination 2011, 272, 128-134. [CrossRef]

115. Shen, L.; Lei, Q.; Chen, J.; Hong, H.; He, Y.; Lin, H. Membrane fouling in a submerged membrane bioreactor: Impacts of floc size. Chem. Eng. J. 2015, 269, 328-334. [CrossRef]

116. Wang, X.; Chang, V.W.C.; Tang, C.Y. Osmotic membrane bioreactor (OMBR) technology for wastewater treatment and reclamation: Advances, challenges, and prospects for the future. J. Membr. Sci. 2016, 504, 113-132. [CrossRef]

117. Wu, Y.; Wang, X.; Tay, M.Q.X.; Oh, S.; Yang, L.; Tang, C.; Cao, B. Metagenomic insights into the influence of salinity and cytostatic drugs on the composition and functional genes of microbial community in forward osmosis anaerobic membrane bioreactors. Chem. Eng. J. 2017, 326, 462-469. [CrossRef]

118. Liu, J.; Wang, X.; Wang, Z.; Lu, Y.; Li, X.; Ren, Y. Integrating microbial fuel cells with anaerobic acidification and forward osmosis membrane for enhancing bio-electricity and water recovery from low-strength wastewater. Water Res. 2017, 110, 74-82. [CrossRef]

119. Wang, X.; Zhao, Y.; Li, X.; Ren, Y. Performance evaluation of a microfiltration-osmotic membrane bioreactor (MF-OMBR) during removing silver nanoparticles from simulated wastewater. Chem. Eng. J. 2017, 313, 171-178. [CrossRef]

120. Cagnetta, C.; D’Haese, A.; Coma, M.; Props, R.; Buysschaert, B.; Verliefde, A.R.D.; Rabaey, K. Increased carboxylate production in high-rate activated A-sludge by forward osmosis thickening. Chem. Eng. J. 2017, 312, 68-78. [CrossRef]

121. Lu, D.; Liu, Q.; Zhao, Y.; Liu, H.; Ma, J. Treatment and energy utilization of oily water via integrated ultrafiltration-forward osmosis-membrane distillation (UF-FO-MD) system. J. Membr. Sci. 2018, 548, $275-287$. [CrossRef]

122. Korenak, J.; Hélix-Nielsen, C.; Bukšek, H.; Petrinić, I. Efficiency and economic feasibility of forward osmosis in textile wastewater treatment. J. Clean. Prod. 2019, 210, 1483-1495. [CrossRef]

123. Volpin, F.; Heo, H.; Hasan Johir, M.A.; Cho, J.; Phuntsho, S.; Shon, H.K. Techno-economic feasibility of recovering phosphorus, nitrogen and water from dilute human urine via forward osmosis. Water Res. 2019, 150, 47-55. [CrossRef] 
124. Vinardell, S.; Astals, S.; Mata-Alvarez, J.; Dosta, J. Techno-economic analysis of combining forward osmosis-reverse osmosis and anaerobic membrane bioreactor technologies for municipal wastewater treatment and water production. Bioresour. Technol. 2019, 122395. [CrossRef]

125. Cath, T.Y.; Hancock, N.T.; Lundin, C.D.; Hoppe-Jones, C.; Drewes, J.E. A multi-barrier osmotic dilution process for simultaneous desalination and purification of impaired water. J. Membr. Sci. 2010, 362, 417-426. [CrossRef]

126. Wan, C.F.; Chung, T.-S. Techno-economic evaluation of various $\mathrm{RO}+\mathrm{PRO}$ and RO+FO integrated processes. Appl. Energy 2018, 212, 1038-1050. [CrossRef]

127. Blandin, G.; Verliefde, A.R.D.; Tang, C.Y.; Le-Clech, P. Opportunities to reach economic sustainability in forward osmosis-reverse osmosis hybrids for seawater desalination. Desalination 2015, 363, 26-36. [CrossRef]

128. Valladares Linares, R.; Li, Z.; Yangali-Quintanilla, V.; Ghaffour, N.; Amy, G.; Leiknes, T.; Vrouwenvelder, J.S. Life cycle cost of a hybrid forward osmosis-low pressure reverse osmosis system for seawater desalination and wastewater recovery. Water Res. 2016, 88, 225-234. [CrossRef] [PubMed]

129. Dreszer, C.; Wexler, A.D.; Drusova, S.; Overdijk, T.; Zwijnenburg, A.; Flemming, H.C.; Kruithof, J.C.; Vrouwenvelder, J.S. In-situ biofilm characterization in membrane systems using Optical Coherence Tomography: Formation, structure, detachment and impact of flux change. Water Res. 2014, 67, 243-254. [CrossRef] [PubMed]

130. Sun, Y.; Tian, J.; Song, L.; Gao, S.; Shi, W.; Cui, F. Dynamic changes of the fouling layer in forward osmosis based membrane processes for municipal wastewater treatment. J. Membr. Sci. 2018, 549, 523-532. [CrossRef]

131. Liden, T.; Carlton, D.D., Jr.; Miyazaki, S.; Otoyo, T.; Schug, K.A. Comparison of the degree of fouling at various flux rates and modes of operation using forward osmosis for remediation of produced water from unconventional oil and gas development. Sci. Total Environ. 2019, 675, 73-80. [CrossRef]

132. Zhao, P.; Gao, B.; Yue, Q.; Shon, H.K.; Li, Q. Fouling of forward osmosis membrane by protein (BSA): Effects of $\mathrm{pH}$, calcium, ionic strength, initial permeate flux, membrane orientation and foulant composition. Desalin. Water Treat. 2016, 57, 13415-13424. [CrossRef]

133. Lotfi, F.; Chekli, L.; Phuntsho, S.; Hong, S.; Choi, J.Y.; Shon, H.K. Understanding the possible underlying mechanisms for low fouling tendency of the forward osmosis and pressure assisted osmosis processes. Desalination 2017, 421, 89-98. [CrossRef]

134. Zhao, Y.; Wang, X.; Wang, Z.; Li, X.; Ren, Y. Nanoparticle fouling and its combination with organic fouling during forward osmosis process for silver nanoparticles removal from simulated wastewater. Sci. Rep. 2016, 6. [CrossRef]

135. Sun, Y.; Tian, J.; Zhao, Z.; Shi, W.; Liu, D.; Cui, F. Membrane fouling of forward osmosis (FO) membrane for municipal wastewater treatment: A comparison between direct FO and OMBR. Water Res. 2016, 104, 330-339. [CrossRef] [PubMed]

136. Im, S.-J.; Rho, H.; Jeong, S.; Jang, A. Organic fouling characterization of a CTA-based spiral-wound forward osmosis (SWFO) membrane used in wastewater reuse and seawater desalination. Chem. Eng. J. 2018, 336, 141-151. [CrossRef]

137. Liden, T.; Carlton, D.D., Jr.; Miyazaki, S.; Otoyo, T.; Schug, K.A. Forward osmosis remediation of high salinity Permian Basin produced water from unconventional oil and gas development. Sci. Total Environ. 2019, 653, 82-90. [CrossRef] [PubMed]

138. Liden, T.; Hildenbrand, Z.L.; Schug, K.A. Pretreatment Techniques for Produced Water with Subsequent Forward Osmosis Remediation. Water 2019, 11, 1437. [CrossRef]

139. Ibrar, I.; Naji, O.; Sharif, A.; Malekizadeh, A.; Alhawari, A.; Alanezi, A.A.; Altaee, A. A Review of Fouling Mechanisms, Control Strategies and Real-Time Fouling Monitoring Techniques in Forward Osmosis. Water 2019, 11, 695. [CrossRef]

140. Goh, P.S.; Ismail, A.F.; Ng, B.C.; Abdullah, M.S. Recent Progresses of Forward Osmosis Membranes Formulation and Design for Wastewater Treatment. Water 2019, 11, 2043. [CrossRef]

(C) 2019 by the authors. Licensee MDPI, Basel, Switzerland. This article is an open access article distributed under the terms and conditions of the Creative Commons Attribution (CC BY) license (http://creativecommons.org/licenses/by/4.0/). 